Portland State University

PDXScholar

\title{
Theory and Poetry: John Ashbery's "Self-portrait in a Convex Mirror"
}

Jeffrey Wayne Timmons

Portland State University

Follow this and additional works at: https://pdxscholar.library.pdx.edu/open_access_etds

Part of the English Language and Literature Commons

Let us know how access to this document benefits you.

\section{Recommended Citation}

Timmons, Jeffrey Wayne, "Theory and Poetry: John Ashbery's "Self-portrait in a Convex Mirror"'" (1994). Dissertations and Theses. Paper 4898.

https://doi.org/10.15760/etd.6774

This Thesis is brought to you for free and open access. It has been accepted for inclusion in Dissertations and Theses by an authorized administrator of PDXScholar. Please contact us if we can make this document more accessible: pdxscholar@pdx.edu. 


\section{THESIS APPROVAL}

The abstract and thesis of Jeffrey Wayne Timmons for the Master of Arts in English were presented May 20,1994, and accepted by the thesis committee and the department.

COMMITTE APPROVALS:
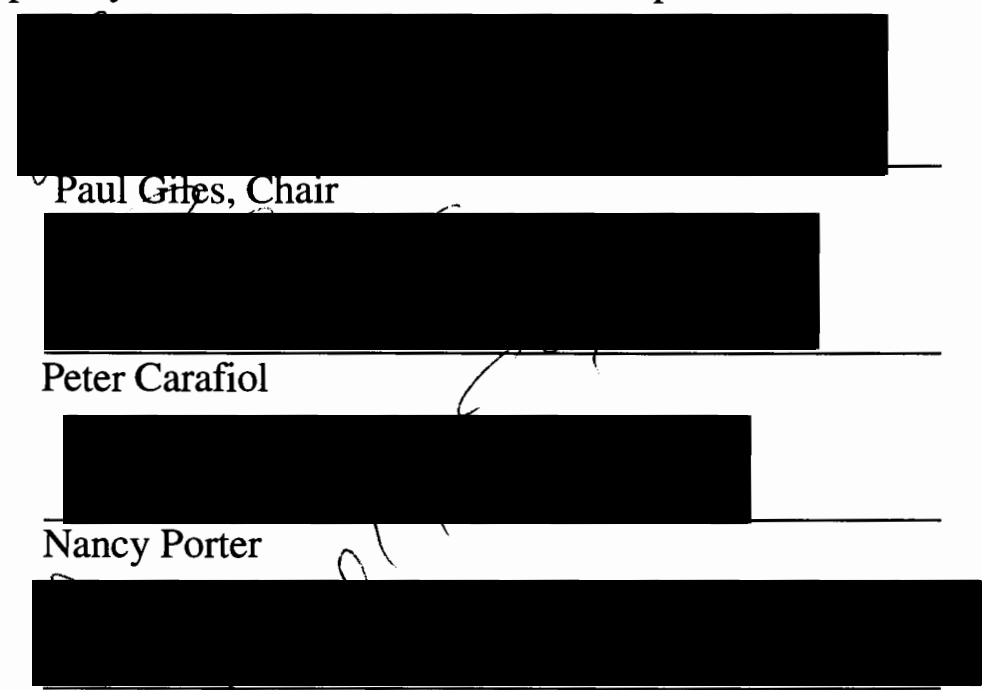

Gregory F. Goekjian

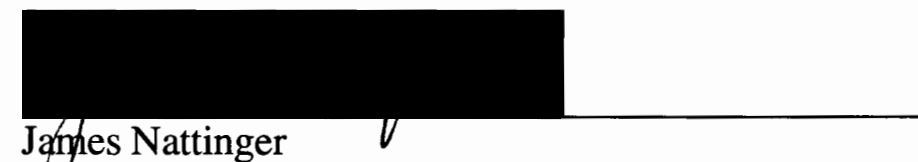

Representative of the Office of Graduate Studies

DEPARTMENT APPROVAL:

Sйeney Reece, grair

Department of English

$* * * * * * * * * * * * * * * * * * * * * * * * * * * * * * * * * * * * * * * * * * * * * * * *$

ACCEPTED FOR PORTLAND STATE UNIVERSITY BY THE LIBRARY

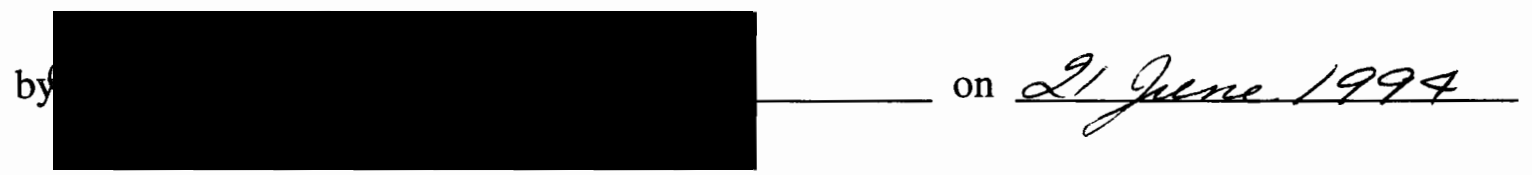




\begin{abstract}
An abstract of the thesis of Jeffrey Wayne Timmons for the Master of Arts in English presented May 20,1994.
\end{abstract}

Title: Theory and Poetry: John Ashbery's "Self-Portrait in a Convex Mirror."

This thesis examines John Ashbery's poem "Self-Portrait in a Convex Mirror" and its revision of the traditional distinction between theory and poetry. Drawing a relationship between the poem's subject and the practices of postmodern theoretical discourse, the thesis posits the poem as an artifact of these changes. Creating a context for the poem, these developments not only inform the climate in which Ashbery's poem takes on significance, but, as well, explain the changing nature of literary study. Historical in its approach to the pressures and impulses within this climate of aesthetic production, the thesis traces the distinction between science and literature and how it has influenced the creation of the literary discipline. Demonstrating that the disciplinary study of literature has always been the subject of debate and discussion, it uses this understanding to place present disagreements about the need or usefulness of theory in the context of historical disagreements over the difference of literature from science or philosophy.

Explaining that postmodern theory has largely worked to foreground the arbitrary nature of distinctions such as that between theory and poetry, the thesis elaborates on how poststructuralism undoes these distinctions to show how they are always the result of particular political and ideological views of representation. Using this critical insight, the 
thesis then reads closely the details of the poem's relationship to postmodern theory, how it works to undo the distinction between theory and poetry.

Having undone this traditional distinction, however, leaves the poem in an ambivalent and unstable position. Since it passes between extant categorical definitions its own nature remains undecided and, thus, maintains an engagement with and resistance to tradition. It remains caught between the need for the aesthetic past and the need for a freedom from that past. Chapter four, therefore, explores this ambivalence, particularly as it relates to the inheritance of romanticism and modernism.

Finally, in chapter five, the thesis revises the main critical perception of Ashbery as postmodern, making a case for his closer affiliation with a late version of modernism. Because of Ashbery's preoccupation with the aesthetic past, his use of the imagery, insights, and idealism of our aesthetic history, he appears to re-create a distinction between high and popular art that is more consonant with a version of modernism. 
Theory and Poetry:

John Ashbery's "Self-Portrait in a Convex Mirror"

by

Jeffrey Wayne Timmons

A thesis submitted in partial fulfillment of the requirements for the degree of

\author{
Master of Arts \\ in \\ English
}

Portland State University

1994 


\section{TABLE OF CONTENTS}

PAGE ACKNOWLEDGEMENTS $\ldots \ldots \ldots \ldots \ldots \ldots$ iii CHAPTER

I Science and Poetry:

Disciplinarity and the Division of Knowledge . . . . . . . . . 1

II Postmodernism: Theory and Poetry . . . . . . . . . . . . 14

III "Self-Portrait in a Convex Mirror": Passing Between Theory and Poetry . . . . . . . . . . . 32

IV Revision of the Literary Past:

Ashbery's (Dis)engagement with Tradition . . . . . . . . . . 50

V Refracting Postmodernism . . . . . . . . . . . 75 


\section{Acknowledgements}

The text represented here is the result of much hard work--though not all of it mine. I want to acknowledge my debt to Paul Giles for taking on the task of guiding this project along and to express my thanks for his insight, advice, encouragement, and, above all, for his reading and rereading of the thesis. I also want to thank Gregory Goekjian for offering criticism and support as well. And while the thesis is the result of much work on the part of myself and others, in the end I accept full responsibility for its short-comings and its successes--be they what they may. 
For Michelle,

who knows the difference. 


\section{Chapter One}

\section{Science and Poetry: Disciplinarity and the Division of Knowledge}

Postmodernism and poststructuralism, as theoretical and aesthetic practices, have come to be a standard part of academic discourse. The critical debate that took place in the academic community concerning postmodernism, about whether it was something unique and distinct from modernism, was accompanied by anxieties and animosities raised about the growing interest in critical theory. The study of postmodernism and the theoretical models developed in order to facilitate this study were seen not only as a threat to extant curriculum and canons, but to the study of "literature" itself. Theory was seen as a threat because it had become more than a supplement or an aide in the study of literature; it had become an object of study in itself. Although these issues are still very much part of critical debate, at this point it is safe to assume that modern critical theory in the study of literature will continue to be a part of the academic landscape for the foreseeable future.

While this situation is lamented by large circles of readers and critics, with some reasonable complaints about the rhetorical excesses of poststructuralist discourse, it should also be clear that the increasing use and production of theoretical discourse has opened up large new areas of research and investigation. It has also gone a long way toward reevaluating the criteria and bases of traditional inclusions and exclusions of texts--opening new avenues for study and providing alternatives to what has come before. In this sense, then, it has reinvigorated the study of literature and offered a new space for a diverse assortment of practices and methods of research that historically fell outside the discipline of "Literature." The large-scale infusion of theoretical discourse about literature has made 
it possible to foreground the sorts of activities that we as critics and readers engage in. As Gerald Graff points out, what theory has made possible is the opportunity to include our students in the debates, in the on-going construction of the object of literary study. This self-consciously theoretical study of literature is a potentially more rewarding method of teaching than simply submitting to students a model of literature predicated on fixed canons which are seen as an expression of a timeless human essence. The discipline of literature, in other words, responding to the insights of contemporary theory, has attempted to engage itself in a process of re-evaluation and debate about the very terms and objects of study. This process of revision and interrogation is to be preferred, at least pedagogically if not professionally, to a discipline unwilling to examine its own premises.

The emergence and rapid growth of theoretical perspectives in the study of literature since the late 1960s has had a tremendous impact on the study of literature as a professional practice. It has had an enormous influence on the ways in which we talk about literature. Although the changes that have taken place in the last twenty or thirty years should be viewed as part of a larger history of the institution of literature, we should not neglect to take into account the particular character of these changes. As Gerald Graff emphasizes in Professing Literature, the history of English literature in America has always been a hotly contested subject of debate. There has been and there remains disagreement and debate over the terms and nature of literature. The curriculum, notes Graff, has never been free of controversy and political debate, it had never been free from discussion about what (and how) literature should be dealt with in the classroom (8). The history of the study of literature is the history of conflict, and how those conflicts affect pedagogy and canons. It is, however, the organized and bureaucratic nature of the "field-coverage" model that has historically masked debates within individual disciplines from students. The tacit assumption behind the cloistered nature of debate, masked by a belief in the humanistic value of literary study, was that students should be exposed only to the results of 
professional controversy and not to the debate itself. Thus, the curriculum, continually determined through time by political controversy and trade-offs that were excised from public view, was presented as a de facto structure free of political rankling and disagreement. This institutional attitude manifested itself in a static and isolated approach to literature, reinforcing the student's perception of literature as the study of discreet and stable "literary objects." In Graff's view, because "the courses in periods and genres did not address one another, teachers tended not to raise the question of what connections or contrasts the different periods and genres might bear to one another, what was meant by a particular periodization.... It was as if categories existed in order to make it unnecessary to think about them and to recognize that they were the product of theoretical choices" (Graff 8). The effect of this was an implicit agreement not to ask how various perspectives and views might be connected or contrasted; it also prevented conflicts from becoming part of literary study (Graff 8-9). This masking of the conflicts also deprived students and instructors of a valuable "means of situating themselves in relation to the cultural issues of their time; for students learn not just by exposure to individual instructors, but by sensing how the teaching aggregate hangs together or divides, so that to obscure these relations robs students of one of the central means of making sense of education and the cultural world" (Graff 9).

Coming as it does in a period that is intent on foregrounding the ideological nature of literature, Graff's "institutional history" shares the critical impulse for revising and examining the ideals, methods, and categories inherited from the past in order to show how they were, and continue to be, the subject of debate and political interests. The changes in the study of literature since the 1960s have made projects like Graff's, which ask questions about the very nature of what it is we study when we study literature, a necessity. We no longer take for granted that literature can and does speak for itself, we recognize that there are always values and political interests being promoted in any act of reading, and this puts 
us in the position of always needing to re-examine the exclusions, distinctions, and canons of the past.

The traditional distinction made between science and literature, between the literary and the non-literary, is just such an opposition inherited from intellectual history. William Paulson, in The Noise of Culture, notes that the distinction between the "two cultures"-science and literature--goes back to Plato, but takes on its contemporary importance with the development of romanticism during the nineteenth century (7-9). Exploring the genealogy of the modern university, Paulson shows how modern divisions of knowledge are the historical result of particular relationships between disciplines and texts. Beginning with the medieval universities, he notes that there were separate divisions but they could not be distinguished "by whether or not they accorded the written word status as an object of study. In all fields, knowledge was sought in texts. The arts, and in particular the seven artes liberales deemed most essential to education, were in a real sense constituted by the texts that made up their curricula" (5). Although the liberal arts were segregated into divisions that suggest a distinction between literature and science, says Paulson (5), they did not differ in taking texts as an object of study:

Knowledge, in other words, was presumed to reside in the written works of those authors who, by their writings, had originated the arts and whom the institutions of learning thus recognized as authorities. The function of the author was to guarantee the authority, the truth, of what was written. (Paulson 6)

It is during the seventeenth and eighteenth centuries, though, that increasingly we see evidence from within "literature" of a division, of a distinction being made between the literary and the non-literary. As Paulson sees it, the growing unease with authority, with the auctores, indicates the early formation of a discursive practice coming to define itself as opposed to the textual or "literary-ness" of literature. Modern scientific culture begins during this period to claim "that knowledge resides in a kind of statement whose truth depends not on authorship but on the procedures by which it is made" (Paulson 6). 
"Modern science," says Paulson, "shuns the traditional seductions of writing, the rhetorical powers of language" (12). Having reached a consensus on how to proceed, science is free to pursue its ends in a standardized manner that emphasizes repeatability and verifiability, not uniqueness or style. There is no longer any reason to engage in what might be termed "literary devices" in order to express empirical data. As Paulson says:

It is true ... that the rise of modern science profoundly altered the status of writing and language in the pursuit and dissemination of knowledge. Science changes qualitatively when it acquires what Thomas Kuhn called paradigms, recognized scientific achievements that define acceptable problems and methods, providing a generally agreed to conceptual context for specialized work. In the preparadigmatic phase of a science, its practitioners often hold incompatible, competing views about the nature of their object and the methods suitable for investigating it. They argue for these views by writing books addressed to one another and to a broad, cultivated audience.... As a scientific community adopts a given paradigm, the status of writing changes. Given the agreement on the nature of the problems to be solved and the general methods for doing so, there is no need for lengthy persuasive arguments on fundamentals. An exchange of information in technical and formalized language replaces the writing of treatises .... Science, by becoming "paradigmatic" and thereby experimentally productive, becomes less literary, less written. (Paulson 12)

It is against the growing influence of science, its discursive habits and ways of describing the world, however, that romanticism first offers the alternative of an "imaginative, autonomous, nonutilitarian writing" (Paulson 12-13). Literature, particularly poetry, became a voice for what culture suppressed in its mechanical and deterministic view of reality. Against this Newtonian world view, romanticism emphasized the organic nature of the individual imagination--from which our modern view of literature emerges (Paulson 13). The poet's way of knowing and describing the world was opposed to that of the scientist's, because while expanding "the empire of man over the external world," according to Shelley, science also circumscribed man's internal world (Paulson 13). The manipulative character of Newtonian science, to the romantics, was equal "to the control exercised by a calculating society over the inner self of the individual. Life, history, human 
thought and emotion--these cannot be understood on the model of a mechanical system, a deterministic interaction of masses and forces" (Paulson 13).

This articulation of the differences between science and literature, each reifying their claims to a form of knowledge vitally distinct from the other, can be seen as an early example of a disciplinary squabble. Science, in the eighteenth century, comes increasing to make claims for itself that formerly fell within the domain of literature. Science then begins to exert pressure on literature to justify its claims as a form of knowledge. Literature, in other words, is suddenly in the position of being forced to confront its own diminished disciplinary status. It reacts by turning in upon itself and theorizing about its importance, its vital place in the cognitive processes of man, as a different and still valuable means of expressing the world.

This is precisely the sort of context within which we must consider the present situation of modern literature, its status as a discipline, and the concerns raised over the growing theoretical nature of the institution. Making a claim for literature's continued importance, the romantic defense of the poetic imagination was a justification of its claims on the attention of its audience. No longer answering the need for scientific knowledge or authority, literature defensively speculates on its own functions and purposes within a culture increasingly questioning its relevance. Marginalized by its status as "fiction" and having no body of knowledge it can call distinctly its own, literature cannot claim to be a separate and autonomous discipline. In turn, in order to survive, literature must construct a set of issues or aesthetics that it alone is capable of examining. This is apparent in various aesthetic developments in post-nineteenth century literature, particularly modernism, New Criticism, and poststructuralism, wherein each seems to be a response to the increasingly difficult position of claiming a role of importance for the artist and/or critic and text. It is as if the romantic realization of the need to justify the place of the artist in a world abandoning aesthetic models for scientific ones is continually replayed in different terms, but with the 
same purpose: to defend aesthetics and the artist as having an important role to play in a culture placing that ideal under critical doubt.

It is understandable, then, that literature has become so increasingly theoretical in the last thirty years--particularly as the ideal of aesthetics as a means toward salvation has largely been abandoned. Having lost this particular form of aesthetic idealism, literature is once again forced into the position of making arguments as to its importance, of justifying its claims on the attention of its audience, of identifying what it is that it does that is valuable, and creating a place for itself in the world. Of course, there are various points of view as to what that role is and should be. That is why the reaction within the discipline to theory is so important; because this divided response, both negative and positive, to modern literature's increasingly theoretical nature is itself a sign of the anxiety about what literature is or should be. The present debate within the literary discipline over the relationship between theory and poetry, about whether we need theory to discuss literature or not, between those who see theory as a separate discourse, recreates much the same sorts of rhetorical positions as the romantic reaction to science did. Now, however, those positions are staked out within literature itself, between those that feel literature is not theory and those that feel theory is vital for the continued presence of literature on the intellectual and aesthetic landscape.

Paulson and Graff point out that literature as a discipline has continually replayed these sorts of dilemmas within itself. Literature as an autonomous discourse has constantly attempted to reconcile its uncertain status as an object of knowledge with its need to remain an object of study in the face of disciplinary incursions on its subject matter. The dilemma has had various incarnations, but remains a constant in discussions of what is or what should constitute literary study. As both Graff and Paulson claim, the introduction of national literatures into the educational curriculum during the nineteenth century is an 
example of the presence of this dilemma early on in the history of the discipline. The new place in the curriculum for English literature was intended to promote not only the ideological and cultural values of society, but to serve also as an area of scholarly study and research. As Paulson says:

On the one hand, the study of literature had to be made into a respectable university research specialty, one discipline among many; on the other hand, it had to assume the function of providing a general cultural education. Scholars and teachers were supposed to make literature into the object of a positivist discipline, imitating the sciences if need be, and they were also supposed to transmit the contents of literature, which were to serve as a synecdoche for the lost cultural totality that once resided in the written tradition but that was now disappearing as science disqualified the authority of the merely written in a growing number of domains. (17)

The establishment of these dual functions within English as a discipline, Graff states, created a "crisis at the outset" in literary study at American universities. Because literary education found itself having to balance out scholarly and generalist conceptions of literary study, conflict was built into the institution from its very inception. This situation grew out of the establishment, in the 1890s, of an effort to standardize college entrance policies and to promote the study of English literature. In 1894, a national conference on college entrance requirements drafted a list of texts for preparation on the exams, a list that "not only gave definition to college English as a literary enterprise, but compelled the secondary schools to conform to that definition" (Graff 99). The problem, though, was that while attempting to consolidate English as a discipline, the adoption of the list demonstrated the conflicts inherent in its study. The 1894 conference is significant because it adopted two lists, one for the "wide" study and another for "deep" study. The adoption of two lists was essentially a compromise between conflicting points of view, between the adherents of "disciplined study" and the "proponents of appreciation," and "humanistic goals" (Graff 100). Even here, notes Graff, at the outset of professionalization in the discipline, there 
are conflicts whose sources lie in competing interests and values which make up English departments.

The institution of literature, contrary to what is depicted in the classroom during this period, is made up of disagreements and conflicts over what and how literature should be taught. The discipline conceals the uncertainty about the literary object, as it finds less and less it is able to call its own subject, and responds with calls for professionalization and a more scientific approach to literary study. Unsure of what belongs to it, the study of literature also attempts to defend itself on the basis of a humanism, a complex of assorted moral and cultural values described as a "universal human essence," which actually cloak the interests and values being promoted as "universal." Thus, serving two contradictory impulses, the study of literature is divided between those that argue for its study in and of itself and those that advocate a more disciplined study.

We can see these competing interests in the emergence of New Criticism. Emerging in its preliminary forms as early as the 1890s, New Criticism grew from a response to the work of research scholars who were seen as having divorced the study of literature from both its aesthetic and social concerns (Graff 122-128). The New Critics believed the research scholars did the study of literature a disservice with their emphasis on the historical, biographical, sociological, and psychological elements of literature. It was a method of study, the New Critics felt, that neglected works of literature by focusing on extrinsic matters. The success of the New Criticism's efforts to restore literature as the object of study was largely the result of a "united front" of nascent New Critics and other assorted camps, who eventually succeeded in marginalizing the more traditional research scholars. As Graff notes, these research scholars had come in for attack on all sides:

from aesthetic formalists and humanistic moralists alike, since, arguably, they managed to $\sin$ in both the antithetical ways that offended each: that is, they confused literature with nonliterary forms of discourse and they divorced it from social and ethical concerns. Against this common adversary, which respected neither the 
morality nor the aesthetics of art, moralists and aesthetes could for the moment feel part of a loosely united front.

(Graff 128)

Part of the commonality of this "united front" was the desire to make literature more available to the general reader by demanding attention to its formal features: the poem as poem, not as biography, sociology, or history. In this way, says Elizabeth Bruss, readers would be able to recognize the qualities of literature itself (13). In order to draw attention to the text itself, the New Critics emphasized the work of art as an autonomous whole and held that its value must lie within the text, not in extrinsic concerns. Distinguishing between what was internal and what was external to the literary work, rejecting extrinsic situations and contexts in favor of an internal analysis, the New Critics, according to Jonathan Culler, left both the reader and critic with only one option: they must interpret, they must show how a work's various parts make up its unity ("Beyond Interpretation" 245). Thus, the main concern for the New Critic, says Bruss, was to "define the nature of the literary object, and thereby establish which critical methodologies were appropriate to it and which were not" (11). Since the New Critics based their work on the autonomy of literature, on how different it was from other discourses, they regulated the accumulation of information about the text to an ancillary role (Culler, "Beyond Interpretation" 245). Although this gave the study of literature more focus and promoted a more precise and relevant understanding of literary works, it also implicitly made literary theory a negative activity (Culler, "Beyond Interpretation" 251)--because it limited the critic to showing how the parts of a text function and deferred to other disciplines questions about the text's history or its status within a culture. Indeed, for the New Critics, the worth of criticism lay in its efforts to protect the autonomy of literature from historical studies or science (Bruss 12): "If the work is an autonomous whole then it can and should be studied in and for itself, without references to possible external contexts, whether biographical, historical, psychoanalytic, or sociological" (Culler, "Beyond Interpretation" 245). 
The New Criticism managed for a time to control the conflicts within itself through its focus and attention to a "stricter, more principled, even "scientific" or theoretically founded, study of art" (Hartman 258). Defending their view of literary texts as an autonomous and distinctly different object from that of psychology or history, the New Critics sought to separate texts from their contexts. Believing literature to be a disciplinary object in much the same sense that history or psychology has a subject, the New Criticism saw the study of the internal organization of literature, as opposed to biographical or contextual study, as the most efficient means of protecting disciplinary status for literature. Stressing the peculiarity of literature, its difference from other types of language, New Criticism worked against attempts to subject literature to verifiability, to treat it as historical, or as autobiographical revelations by the author. The New Critics objected to these methods as trivializing the aesthetic experience of reading and ignoring the "specificity and integrity of literary constructions" (Bruss 11). However, with its prohibition on "ideas, psychology, social relations, and other extrinsic disciplines," the New Critics isolated literature from anything but itself, detaching and removing it from work in other disciplines (Bruss 13).

The increased attention to internal order is most apparent in the New Criticism's practice of close reading. Arising from a need for a greater focus on the literary object itself--without the distraction of history, veracity, or practical value (Bruss 12)--close reading also distances literature from any relation to context or situation. In their efforts to impose restrictions on various approaches to texts and in attempting to bracket off literature (particularly poetry) from other types of language, New Criticism created a self-destroying conflict within itself: by imposing its own critical devices, New Criticism implicitly acknowledged that meaning was created, not as they believed, by the object itself, but by the method used to examine it (Bruss 14-15). New Criticism was unable to see the irony it had created within itself. That is, while promoting the reading of texts themselves, not as 
biography or psychology or philology, the New Critics implicitly argued for theory as a way to interpret works of art. Thus, theory, in the shape of history or psychology, is seen by New Criticism as outside literature, part of another discourse, which only offers a way of talking about literature and not a way of talking about literature itself. But in arguing for their own "more scientific" approach to textual study, the New Critics argued for the use of theory, for the application of their method of examining texts. Hence, the contradiction that Bruss and Graff identify arises out of the use and denial of theory: when reading is seen as an activity, a strategy, or attempt to apply meaning to a text rather than the text determining meaning, reading is freed from "reverent responsiveness" to the literary object. New Criticism, believing itself to be "objective" in plumbing the text for meaning, actually exposes the manner in which meaning is created in a text by the critical method used to examine it. However, "the ultimate consequence of the 'decline of the object' is the liberation of literary theory to determine its own proper ends, no longer ruled by what the object itself seems to demand--a demand that . . . always smacked of circularity, since the object was actually a product of theoretically imposed definitions in the first place" (Bruss 15). In addition, notes Bruss, when form at last begins to appear neither determining nor determinant but itself dependent for its completion upon social and semiotic conventions, the way is opened for an assault on the dichotomy between intrinsic and extrinsic approaches to literature (15).

The division and separation of science and literature, then, has shaped the nature of literature, even from within the discipline devoted to its study. Literature, having taken its leave of science, appears to replay the distinction made between them throughout its own institutional history. Within the modern discipline of literary study, the opposition between theory and literature still permeates debates over new approaches and methods for literary study. Although the debate takes on new character and form, it is a reproduction of that cleaving of science and literature, that distinction between a way of talking and a way of 
talking about talking. This distinction between such apparently different modes of discourse as theory and poetry, between the object of study and the methods used to study it, are the very oppositions that our contemporary critical energies have come to bear on. It is also the context of John Ashbery's "Self-Portrait In A Convex Mirror." 


\title{
Chapter Two
}

\author{
Postmodernism: \\ Theory and Poetry
}

I

\begin{abstract}
The idea of poetry is often contrasted with that of thought, and particularly 'abstract thought.' People say 'poetry and abstract thought' as they say good and evil, vice and virtue, hot and cold. Most people, without thinking any further, believe that the analytical work of the intellect, the efforts of will and precision in which it implicates the mind, are incompatible with that freshness of inspiration, that flow of expression, that grace and fancy which are the signs of poetry and which reveal it at its very first words. If a poet's work is judged profound, its profundity seems to be of a quite different order from that of a philosopher or a scientist. Some people go so far as to think that even meditation on his art, the kind of exact reasoning applied to the cultivation of roses, can only harm a poet, since the principal and most charming object of his desire must be to communicate the impression of a newly and happily born state of creative emotion which, through surprise and pleasure, has the power to remove the poem once and for all from any further criticism.

Paul Valéry, "Poetry and Abstract Thought"
\end{abstract}

The work of John Ashbery is frequently referred to as postmodern. His subverting, deflating, and leveling of language has been hailed as the embodiment of literary postmodernism. The bringing down of ideals and expectations, the reduction of language to a surface phenomena, and the mixing of high and popular culture all attest to what in Ashbery we consider postmodern. Ashbery's identification as postmodern, though, obscures a problem in making such a distinction. All too often "postmodernism" becomes a catch-all term for anything that has happened since 1960, without taking into account more specifically what it might entail. When this happens, postmodernism is subject to criticism for having no well-defined characteristics of its own, of having a 
parasitic or ill-defined sense of its own nature, of taking modernism to its absurd extremes and, thus, as having no specific identity of its own. These "non-characteristics" are what constitute postmodernism. But it is as if the whole point of being "postmodern" were lost on those who only see a lack of originality or uniqueness. An important aspect of postmodernism consists in drawing our attention to the very process of how terms like "originality" and "uniqueness" condition particular responses to art. While this mode of aesthetic self-referentiality may be troublesome for some critics and audiences, it states quite clearly what postmodernism is: the problematization of rigid distinctions, boundaries, categories, and periods. Is it any wonder that postmodernism lacks in uniqueness or originality? These are the very ideas that it seeks to render problematic.

Ashbery's association with these postmodern impulses, though, particularly in a poem like "Self-Portrait," is too often a reactive and reductive critical gesture. Simply calling the poem postmodern conceals the poem's own ambivalence towards its status as a unique literary object. The poem stands in too oblique a position on the issue--will it or won't it be (post)modern? Not to examine its anxiety about itself is to overlook the poem's own explicit subversion of specific temporization and periodization. In other words, the distinction between modernism and postmodernism is exactly what the poem sets out to confuse. To call it "postmodern" is to say that it falls one way, when in fact it could just as easily be the other. What "postmodern" should suggest in its association with Ashbery, more than any clearly defined set of aesthetic practices or principles, is a suspicion or a hesitancy towards rigidly determined boundaries and distinctions.

Ashbery's identification as postmodern is particularly interesting as it comes at roughly the same time as critical theory became widely accepted in American universities. This simultaneity is significant because it suggests a shared cultural paradigm. At the same time as Ashbery was writing poetry dealing with the difficulty of stepping out of the conventions that make thinking possible, critical theory was at work displacing the 
traditional models, distinctions, and periods of literary study. Concerned that its own institutional history of distinctions and discriminations had been made at great political and social cost, literature saw theory as an efficient means for making explicit the too often implicit hierarchies, exclusions, and values transmitted by language. While "critical theory" was not entirely "new," it brought about an important reorientation and an increased exchange between modern disciplinary divisions. This reorientation, a blurring of the distinctions between separate disciplines, has its counterpart in Ashbery's own ambivalence. In both critical theory and the work of Ashbery, postmodernism turns distinctions into an object of interrogation, exposing them as the site of political contingencies and positions by foregrounding its own. Ashbery questions the poem as an "original" composition, questions its "autonomy"; the study of literature questions "literature" as a discipline, questions the claim to the possibility of "objective" study. By making readers and audiences more aware of the choices and exclusions that go into the making or interpretation of any work of art, postmodernism demands an awareness of those conventions that frame the possibility of response. That is, in compelling the audience to confront the constructed nature of a work, post-modernism demonstrates the arbitrariness of distinctions believed to be natural, timeless, or essential.

The distinction that is often made between poetry and theory is a particularly important aesthetic and intellectual division. The distinction made between these seemingly opposed ways of talking about language is still very much part of the contemporary debate on poetry and poetics. It is a distinction still with us and frames the terms of the debate. Hank Lazer observes the presence of this distinction in his essay "Critical Theory and Contemporary American Poetry" when he asks: "What is, or what ought to be, the relationship between critical theory and contemporary American poetry" (248)? It is a question worth asking, says Lazer, because it has effects upon the shapes and practices that such oppositions create in the study of literature. While there is a great deal of inter- 
disciplinary work being done at present that can be seen as a result of the interest in critical theory, says Lazer, "there remain certain thorny oppositions within English departments and literary studies that deserve attention and questioning. Indeed, there are certain entrenched prejudices which, for the sake of both critical theory and contemporary American poetry, require some discussion" (248). Primary among these prejudices is the distinction made between theory and poetry, criticism and literature. These sorts of distinctions and divisions take on institutional shape within departments of English and the university as a whole in the way they distinguish between areas, genres, and periods of knowledge and specialties. Distinctions and divisions that exert their influence through the privileging (and deprivileging) of certain modes of poetry, as well as through the promotion of particular methods by which poetry can or should be taught. English departments, for example, reinforce the supposed distinction between creative and critical writing through their choices of teaching positions, specializations, and course content (Lazer 248). This intellectual segregation, says Lazer, even to those that question its institutional shape, remains largely unchallenged because of the institutional and pedagogical consequences of undermining the positions and hierarchies of literature as a discipline.

Lazer notes that the enforcement of a boundary between theory and poetry on an institutional level is a repetition of Plato's banishment of the poets from the realm of serious thinking (249). The oppositions we have inherited from this distinction and its historical repetition have permeated our present understanding of the relationship between poetry and theory and prevent us from seeing the relationship between critical and creative writing in ways that might reveal compatibilities and areas of shared interest. The distinction sets into opposing camps the poets and the theorists, both of whom argue over who has the authority to say what poetry is or is not. The distinction, too, frames the terms of the debate; given that the theoretical is claimed by the theorists and critics, poets often argue 
from a non-theoretical position. The anti-intellectual, anti-theoretical stance of many poets who argue against theory as a way of understanding their work is framed by the distinction between theory and poetry just as much as that of the theorist's assertions of "the death of the author."

A typical example of the opposition between theory and poetry, says Lazer, is Karl Shapiro's declaration in the 1960 volume In Defense of Ignorance: "If poetry has an opposite it is philosophy. Poetry is a materialization of experience; philosophy the abstraction of it" (Lazer 248). Shapiro's attitude towards what he feels is a hard and fast distinction between poetry and philosophy remains common:

Similar remarks can be found in the essays and interviews of poets such as Robert Bly, Louis Simpson, Philip Levine, and countless others. In "A Wrong Turning in American Poetry" (1963), a seminal essay for American poetry of the sixties and seventies, Robert Bly, while advocating an inward, spiritual turn in American poetry, takes potshots at the overly philosophical poetry of his immediate predecessors. He attacks Eliot for working up "the poem as an idea". .. and criticizes "the Metaphysical Generation," the American poets of the twenties and thirties, because "not only were these poets ... profoundly influenced by the English metaphysical poets, but their basic attitude was detached, doctrinaire, 'philosophical' . ..." (Lazer 249)

Negative reactions to "the poem as idea" are still very much with us, however, and still make up part of the debate on the nature of poetry and its difference from theory. Jonathan Holden, for instance, whose "practical criticism" attempts to separate the practice of theoretical criticism from poetry, is very much part of recent affirmations of the historical distinction made between poetry and theory. In his book The Fate of American Poetry, Holden shows how the professionalism of creative-writing programs has led not to a marginalization of poetry, but rather to the creation of a captive audience for it. Poetry, argues Holden, has broadened its audience within and through the university, used it as the basis of a popular audience (14). Holden's attitude toward professionalization and the poetry produced by it, though, is troublesome. While the university has widened the 
audience for poetry, says Holden, it has also created what he feels to be a great deal of "mediocre" poetry:

When an art form is produced en masse, most of it will conform to the fashion of the moment, be merely competent. But why feign surprise or disappointment in this? Mediocrity is present in every human endeavor. (Holden 14)

What is clear in Holden's leveling of the charge of "mediocrity" is that some poetry, some types of poetry produced by "professionalization" are not what he considers to be good poetry. Holden is out to salvage what he considers to be good poetry, but in order to do so he feels he must sift through the vast amount of mediocrity produced by professionalization in order to find those poems that "could interest any serious reader, not just specialists in an English department" (10).

Believing that professionalization has had both positive and negative effects on the production of poetry, then, Holden attempts to show why those poems he considers important are those that tell a story. Professionalization, according to Holden, has led to the dominance of the lyric mode of poetry. The problem with the dominance of lyric poetry, Holden feels, is that it marginalizes poetry from the lives of non-professionals (17). Professionalization of poetry, says Holden, removes it from any serious claim to anyone's attention outside the university--especially in the form of the lyric which delimits its ability to speak to nonprofessionals in its renunciation of telling of stories (3). Holden argues for seeing the value of lyric poetry in its ability to tell stories that "struggle for those larger truths about life." It is the ability of the lyric to render a model of experience that makes it important to readers. The problem with Holden's view of lyric poetry, though, is not so much what qualities he values the lyric for as much as it is the particular values he promotes in his view. While Holden acknowledges the importance of the poem foregrounding itself as language, he values the lyric not for its formal features as a poem, but for its recreation of experience. It is a poem's suggestion of "the larger truths about 
life" that give it value and importance, says Holden. Speaking of Brendan Galvin's "Seals in the Inner Harbor," Holden says:

the main task of a good poem like Galvin's is to render, often but not always in miniature, a model of the structure of experience itself. What kinds of experience? Traditionally, the experiences are those of initiation, involving love, death, seasonal change, natural process.

The rendering of structure, however, is not the only task that the "shortish poem" can perform. Let us look at a second "lyric." This one, by William Stafford, does contain ... some of "those larger truths about life the discovery of which is the final justification for reading." (Holden 6-7)

What should constitute a good lyric, what constitutes a valuable lyric, according to Holden, is a focus on the "struggle for those larger truths" that are the "final justification for reading." It is not the poem itself which is the final justification for reading, but the way the poem recreates life and experience. Holden continues, in reference to the Stafford poem:

If Galvin's poem needed little or no critical mediation, this poem needs even less. Its depiction both of the loneliness of pain and of its protagonist's moral courage is nearly overwhelming, and in sentences as memorable and wise as the most potent Biblical scripture .... (Holden 7-8)

One should give credit to Holden's acknowledgment of the status of generic overlap, particularly as it relates to the prose-verse distinction, as well as to his recognition of the poem as a form of artifice that foregrounds its status as language. However, it is his continuing insistence on reading poems, in the end, as pictures of and reflections on experience that falls short and keeps him from any seeing value in lyric poems that do not "tell stories." Reducing poetry to the most facile humanistic criteria, Holden argues for the effacement of any critical act in the process of reading. Holden's expression of how both Stafford's and Galvin's poems need little if any critical mediation, as if they were as "memorable" and "potent" in meaning as the Bible, argues for an unencumbered, unmediated reading experience. In describing this unmediated experience, akin to what he 
believes reading Biblical verse is like, Holden denies the role a reader plays in shaping meaning; he denies the mediation that must take place in the situation of being separated by time and place from authorial intention; and he denies the role a reader's own experiences, values, and history play in an act of reading. What is most suspicious about Holden's views, though, is that they attempt to promote a particular mode of poetry, a style that doesn't need critical mediation, and that speaks of those "larger truths" which, like the Bible, apparently do not need critical mediation. Holden's argument for an unmediated experience of literature is made in the belief that such an experience is possible and, more importantly, it promotes its own values, judgments, and practices of reading while denying their status as a way of reading. Couched in terms of an unmediated experience of literature, Holden denies that his own views of why poetry should be read are just as much bound up in a particular set of values as the most explicitly theoretical approach to reading.

Holden's bias becomes increasingly evident in his chapter-length evaluation of the state of the poetic art, especially where he derides the production of poetry that seems, to him, made with theoretical explication and comment in mind:

Wallace Stevens, whose meditative later poems are models for Ashbery ... has replaced Eliot at the head of the modernist canon; and various strands of High-Theoretical criticism ... have replaced the old New Criticism. Like the New Criticism, these newer approaches have developed their own specialized jargon and place heavy emphasis upon close reading of "texts"; but unlike the New Criticism, they have refused to take for granted any reliable relation between words and what they might signify. Stevens's approach to language--his poetic demonstrations of the ways in which language predetermines how we view the world instead of describing already known phenomena--has turned out to be almost tailor-made for critics interested in applying fashionable Theory to current poetry. (Holden 42)

While there may be some degree of truth to the comments here, particularly since Ashbery has been over-used in displaying contemporary theory's usefulness, Holden's critical prejudice against the theoretical in poetry or criticism prevents him from finding any value in poetry that deals less with "telling stories" than with its own status as an aesthetic object. 
His resistance to theory and theoretical poetry, though, not only repeats the historical and institutional oppositions and distinctions, but invests them with the imperative of protecting poetry from the theorists. The conscious effort on the part of poets and critics associated with postmodernism to bring our attention to arbitrary distinctions made between theory and poetry threatens Holden. He laments the apparent intrusion of theory into poetry, a situation in which he feels the poets lose out to critics. The implication for the dominance of theory is quite obvious, says Holden: "critics, not poets, are custodians and interpreters for all of us of 'our cultural heritage"" (44). Holden's comments are valid as much as they reflect changes in poetry, as they observe the overt intrusion of theory, theory-bound discourses, and hybridizations of literature and theory into the supposedly "non-theoretical" domain of poetry. But the problem lies in seeing any aesthetic production, including poetry, as "non-theoretical," and promoting that idea of poetry as the only acceptable model. There are always positions being taken in the choices and exclusions of representation; postmodernist theory and art simply attempts to foreground its strategies in such a way that the perceiver comes to recognize representation as the sum of conscious choices and exclusions. Telling stories, therefore, becomes more difficult when working from such a position, and more theoretical. To fault postmodernist practices for drawing our attention to the constructed nature of aesthetic representation is to fault it for the very same critical insights it is able to offer us. This is particularly important, especially since the hybridizations of theory and poetry of which Holden disapproves have given rise not only to the present debate about poetry, but, as well, to an increased dialogue between historically distinct divisions of knowledge. 
The intensity of interaction and exchange between contemporary theory and poetry has largely been the result of theory's recognition of the importance of language. Sharing a preoccupation with the way meaning is shaped within the structures of language, both postmodernist theory and poetry draw attention to the devices of signification rather than to any inherent or natural meaning. It is largely because of this critical gesture that postmodern critical theory and poetry alienate readers and critics like Holden. Since much recent theoretical writing takes as its goal not "necessarily to clarify the meaning of a particular poem or poet's work" (Lazer 258-259), readers are often frustrated by its refusal of fixed meanings and by its excessive self-consciousness. Lazer suggests that this frustration is a response to the greater demands placed on the reader by theoretical writing, but to reject it for making explicit what remains implicit is to reject the very stuff of theory and poetry: language (258). Thus, what Lazer sees in recent poetry is also what much of recent critical theory has come to acknowledge as its own preoccupation: an awareness of language as the site and materials for the creation of meaning. Having a common understanding of language as providing the material basis for the construction of meaning, then, postmodern theory and poetry no longer need to be in a necessarily antagonistic relationship. As Lazer points out, not only do postmodern theory and poetry acknowledge their status as language, they also indicate how all constructions of language are subject to its processes. "If there is a degree of arbitrariness and play built into language, if words do not adequately name or represent things, then not just poetry but philosophy too is subject to this imprecision," says Lazer (261). This self-conscious attention to the conditions and materials of language in postmodern theory and poetry has made both less concerned with 
rigid distinctions between them, since both take as their subject the processes of representation within language. This view of language as a location for the construction of meaning, how all creations within it are subject to its processes, provides a shared paradigm for poets and philosophers and subverts the distinction between theory and poetry (Lazer 261). Both acknowledge the arbitrariness of the distinction between them.

Valéry suggests in this chapter's epigraph that the distinction between poetry and abstract thought is one that seems quite natural and valid to us (52). Coming after the Romantics, it is understandable that we see literature, particularly poetry, as an autonomous and quite different way of describing the world than that of science or philosophy. Valéry points out, though, that this distinction may have more to do with "scholarly" categorization and segregation of the Platonic sort than it does any clear and real difference between the two (52-53). Instead, he says, the distinction is the likely result of an antithesis adopted without reflection and repeated so often that it finds itself firmly fixed in our minds. Valéry's subsequent undoing of the distinction between poetry and abstract thought, however, rests on the observation that all discourse, whether poetry or science, philosophy or drama, uses a language that undermines the fixity of meaning we attribute to it:
Each and every word that enables us to leap so rapidly across the chasm of thought, and to follow the prompting of an idea that constructs its own expression, appears to me like one of those light planks which one throws across a ditch or mountain crevasse and which will bear a man crossing it rapidly. But he must pass without weighing on it, without stopping--above all, he must not take it into his head to dance on the slender plank to test its resistance.... We must not lay stress upon them, or we shall see the clearest discourse dissolve into enigmas and more or less learned illusions. (Valéry 55-56)

The meanings and distinctions that are constructed within language are part of a system that allows its use only as long as its terms are not made to stand for something concrete 
and solid. The distinction, then, that has been constructed between abstract thought and poetry is an opposition that does not hold up to intense interrogation, since both are phenomena of a language-system whose distinctions are subject to contingency and tenuousness.

Valéry's observations about language being a system whose structure is built upon contingency and tenuousness is much the same view that dominates critical perspectives within postmodernism. Operating as it does from this critical observation, postmodernism and poststructuralism seek to undo the sorts of oppositions and distinctions that have been inherited from intellectual history and to show how these "discriminations" have been used to reinforce certain cultural values as "natural." Pointing out that poststructuralism is characterized by its attention to language as a site for the construction of meaning, Jonathan Culler stresses that poststructuralism bases its critique on a model that puts to work linguistic rather than thematic or historical methodologies. Poststructuralism's most distinguishing habit, though, is its blurring of the distinction between what one has to say and the tools one has to say it with. That is, according to Culler, poststructuralism is not so much post-structuralist because it refutes the claims of structuralism or notes the waning of interest in structuralism; rather, a post-structuralist account is one that takes the position that there is no place outside of a cultural practice to describe that practice from. Poststructuralism, according to Culler:

is a critique of a particular account of the structuralist project, the view that one was positioning oneself outside a cultural practice and describing its rules and norms. It is a critique of the view that could get outside and above a domain one was describing. The term poststructuralism would thus most accurately be used to designate the claim that structuralist analyses are caught up in the processes and mechanisms they are analyzing. ("Poststructuralist Criticism" 173)

Poststructuralism, then, is that "analytic posture" that acknowledges not a scientific detachment from what it purports to describe, but, instead, one of involvement. The 
method used to study an object, according to poststructuralism, does not provide a metalanguage through which one would be able to objectively describe that object; the method or habit of language used to describe an object is "problematically caught up in the processes and functions of the phenomena it is studying" (Culler, "Poststructuralist Criticism" 173).

The lack of a metalanguage in the poststructural perspective is important because it recognizes an essential "literariness" within language. There is no language to talk "objectively" about the construction of meaning since meaning is constructed within language and language contains a "literariness" that is part of all human sentences--whether they are theoretical or literary, poetic or philosophical, novelistic or journalistic. Language is literary or figurative always already, because what language refers to is not something outside of it but within its structure. There are only deferrals and displacements within the system and no absolute position outside of it in which to speak non-figuratively. There is no meta anything, only the material of language to be worked with. As Culler puts it: "Philosophical enquiry also demonstrates the inescapable centrality of figurative language: the very attempt to separate literal from figurative depends on concepts which themselves are scarcely free of rhetorical qualities ..." ("Poststructuralist Criticism" 168). Thus, like Valéry's undoing, poststructuralism's undoing of the distinction between the literal and the figurative fixes its attention on the necessity of the interrelation of such terms as literal and figurative in discursive operations. As Culler points out, the desire to separate the literal from the figurative is dependent upon language, which never makes present what it refers to, and so is always already figurative, and, thus, literary.

Culler believes that the increasing interconnection among academic disciplines has been the direct result of recognizing the linguistic nature of the construction of meaning ("Poststructuralist Criticism" 168). The greater interaction across disciplines 
has provided the development of an "expanded rhetoric," a rhetoric which allows a "study of textual structures and strategies in their relations to systems of signification and to human subjects" (Culler, "Poststructuralist Criticism" 169). In other words, the exchange between disciplines has made a wider vocabulary available to all fields of study and has done so by opening interpretive doors with the understanding of the textual/verbal nature of the construction of meaning. In fact, as Culler points out, this also provides a sense of unity in the theoretical/critical enterprise as it is now practiced; for if the canon no longer provides a clear basis for the literary field--since the various theoretical views have constructed alternative canons--a sense of unity among various perspectives emerges from their attention to the mechanisms of making meaning (Culler, "Poststructuralist Criticism" 169). As Culler notes, criticism and theory are now considered "the science of literature or more generally of discourses not devoted to interpreting texts but to investigating the conditions of meaning, the rules and conventions that make meanings possible. .." ("Poststructuralist Criticism" 172).

Noting how the expanded rhetoric of criticism and theory has come to dominate academic discourse, providing a means for greater interaction and exchange among disciplines, Richard Rorty calls this development the "linguistic turn." The "linguistic turn," says Rorty, emphasizes that where there are no sentences there is no truth, that only sentences can be true or false, and that "human beings make truths by making languages in which to phrase sentences" (Rorty 9). Truth, thus, cannot exist independently of human minds; it cannot be "out there" independent of the human mind which thinks in sentences because, says Rorty, sentences cannot exist "out there": "The world is out there, but descriptions of the world are not. Only descriptions of the world can be true or false. The world on its own--unaided by the describing activities of human beings--cannot" (Rorty 5). Sharing this view of language, separate divisions of knowledge now have a means by 
which to negotiate their differences. Understanding language as the material within which we construct meaning, Rorty argues that this creates the possibility of a "passing theory," an intermediary discourse able to negotiate the differences between opposing vocabularies without eliminating them or subsuming them to each other. Believing that it is no longer in our best interest to replay the traditional oppositions and distinctions of the past, Rorty suggests that we not see as "opposed" different varieties of discourse and their separate vocabularies. In praise of the philosophers and writers he finds most useful, Rorty believes their importance is precisely their dissolving of inherited oppositions rather than solving them. In doing away with the need to see oppositions as needing reconciliation or synthesis, we cease to see in opposition the terms and competing vocabularies that form such distinctions. To continue to see these terms as opposed is to posit some position that could encompass both and cancel their difference. On the contrary, says Rorty :

if we were able to bring ourselves to accept the fact that no theory about the nature of Man or Society or Rationality, or anything else, is going to synthesize Nietzsche with Marx or Heidegger with Habermas, we could begin to think of the relation between writers . . . as being like the relation between two kinds of tools--as little in need of synthesis as are paint-brushes and crowbars. ... Both are right, but there is no way to make both speak a single language. (xiv-xv)

Rorty makes it possible, then, to abandon the need to see the difference between theory and poetry as needing to be reconciled or synthesized. Both terms are a necessary part of any discourse and both are useful for different purposes, argues Rorty, and therefore make it possible to evaluate in alternative terms the contributions opposing vocabularies create. Rather than simply bringing opposed arguments together in hope of a synthesis--which Rorty says is consonant with the view that there is a single truth to be expressed (xvi)-Rorty is able to affirm various sorts of "literary" activities as offering insights as equally relevant as those of science or philosophy. In turning away from the need to 
reconcile competing vocabularies into a single one, we are able to account for the differences that make them up rather than doing away with them. As Rorty says:

Such a turn would be emblematic of our having given up the attempt to hold all the sides of our life in a single vision, to describe them with a single vocabulary. It would amount to a recognition of what ... I call the "contingency of language"--the fact that there is no way to step outside the various vocabularies we have employed and find a metavocabulary which somehow takes account of all possible vocabularies, all possible ways of judging and feeling. (xvi)

Instead of positing a single vocabulary that would cancel the differences between competing vocabularies, Rorty argues for a "passing theory," a provisional vocabulary that is constructed in order to negotiate the differences between vocabularies:

Think of such a theory as part of a larger "passing theory" about [another] person's total behavior--a set of guesses about what she will do under what conditions. Such a theory is "passing" because it must constantly be corrected to allow for mumbles, stumbles, malapropisms, metaphors, tics, seizures, psychotic symptoms, egregious stupidity, strokes of genius, and the like.... To say that we come to speak the same language is to say ... that we tend to converge on passing theories. [All] two people need, if they are to understand one another through speech, is the ability to converge on passing theories from utterance to utterance. (Rorty 14)

Thus, a distinction such as that between theory and poetry, is one that is negotiable by a "passing theory," a theory that attempts to establish some sort of communication between speakers of different vocabularies without canceling the differences that have hitherto existed between them.

Using the idea of a "passing theory," Rorty's readings of various "literary" and "philosophical" writers derives from the poststructuralist account of language and bridges what might be seen as a gap in the vocabularies of theory and literature. It is a passing theory, an expanded rhetoric, which undoes the traditional distinctions and oppositions between them in order to reinscribe their differences in an altered form. As Rorty's discussion of Derrida makes clear, what appeals to him is not so much the literary or 
philosophical quality of a work such as La Carte Postale, but the way in which the work exceeds the criteria of either categorical opposition. It simply doesn't pay us to use the distinctions "literary" and "philosophical" in order to talk about such a text. As Rorty says about La Carte Postale:

is it to be judged by 'literary' rather than 'philosophical' criteria? No. . . because there are no antecedently available criteria of either sort. The more original a book or a kind of writing is, the more unprecedented, the less likely we are to have criteria in hand, and the less point there is in trying to assign it to a genre. (135)

Not only is the difference between literal and figurative undermined to show how all discourses partake of the "literariness" of language, but, also, the difference between literature and philosophy is negotiated by the recognition of how these categorizations are arbitrarily agreed upon and have no "absolute" criteria that keep them at a safe distance from each other. A "passing theory," then, is one that undoes the distinctions to allow an increased exchange between them. That is, while maintaining that literature and theory are different discourses and cannot be subsumed by the other or to another discourse that would contain them, Rorty also holds that a "passing theory" allows communication between them, allows the construction of discourses that exceed judgments based on oppositional criteria: is it literature or is it theory? This, says Rorty, is a question that may no longer be of much use to us.

In various ways, then, Rorty, Culler, Lazer, and Valéry all suggest that the relationship between poetry and theory is not only an opposition that has come to seem fixed to us as a result of intellectual reinforcement, but one that in the postmodern era has come under suspicion on the basis of its construction as and within language. Given that theory has no recourse to a metalanguage to talk about poetry, it is in the same position as poetry--it must use the same resources in order to construct meaning. Postmodern theory, having recognized the linguistic nature of the construction of meaning, works to demonstrate this principle by becoming "literary" itself, by blurring the lines between 
literature and theory, between poetic discourse and critical reflection. And in John Ashbery's case, poetry blurs the line between itself and theory. 


\section{Chapter Three}

\section{"Self-Portrait in a Convex Mirror": Passing Between Theory and Poetry}

Using Rorty's idea of a "passing theory," we can now examine more closely the relationship between the concerns of postmodernism and Ashbery's long poem "SelfPortrait in a Convex Mirror." A "passing theory" will allow us to negotiate the interaction of postmodern theory and contemporary poetic discourse and the effacement of the rigid differences between them. Using as our guide postmodernism's revision of representation and language, this section will explore how Ashbery works with these ideas and will show how his treatment of them shares the postmodern climate.

Several key poststructuralist concepts occur in Ashbery's "Self-Portrait," among which the most important are those concerning language and representation. Poststructuralism has taken as its main focus the critique of the view of language (especially written language) as a fallen copy of the transcendental signified--the ideal meaning that is only partially and incompletely indicated by the copy that is language and writing. Language, then, as a system of representation, comes to be seen by poststructuralism not as an expression of some transcendental meaning, but as representing representation itself. That is, rather than seeing the purpose of language and representation as the expression of some idealized essence or contact with the divine, poststructuralism attempts to valorize the materials of representation itself; the signifier takes precedence over the signified. Poststructuralism attempts to recover language and writing not as a medium expressing the transcendental, but as the material of consciousness itself. As was pointed out earlier, the attention given to the linguistic structuring of consciousness is part of an interrelated 
complex of ideas that emanate from poststructuralism's view of language. Starting from the position that language is an arbitrarily agreed upon set of conventions with no necessary relation between the word and the thing it refers to, poststructuralism extends this conception to reevaluate not only language, but also knowledge, the ability to know, and the knower who forms a self within language. Emphasizing how meaning resides in chains of signification, in the systems of representation built on differences, and not within a single stable point of reference or origin which would guarantee meaning, poststructuralism argues that consciousness created within language is not a stable phenomena, but one bound up with the processes of language. The notion of the "subject," in other words, is undermined. Subjectivity becomes more the product of the signs used to discuss and indicate it than some transcendental essence that eludes representation. Most importantly, though, is the impossibility of a meta-language. There is no language or theory available to us, according to poststructuralism, that offers us an unproblematic medium through which to analyze an object of study. The perspective used to examine an object is as caught up in the problems of representation as the object itself. This lack of a metalanguage means that there is no escaping the systems of signification which prevent stability and certainty, no way of positing a transcendental ideal except as a construction within language always subject to displacement and deferral. Theory, then, becomes as bound up in language as poetry. Any positing of a radical and unalterable distance or difference between them cannot be upheld since the distinction itself is dependent upon notions of figural and literal usage that are themselves figurative. Theory and poetry are not two completely separate and distinct acts of knowing and saying, they are both language, both acts within language. In fact, as Ashbery suggests, the bringing together of poetic act and critical reflection in a single process in the poem is an effective strategy for the undoing of the distinction between them. 
Language for the poststructuralist, then, is a system of representation that never guarantees the presence of the thing referred to. There is never a single expressible relation between signifier/signified, only the possibility of further reference that has no consolation of finality. As a means of representation, language does not guarantee the stability of ideas such as self, author, or origins. In fact, language guarantees their instability. Consciousness, subjectivity, the individual, the self, are all the result, all effects of language, of representations made possible by language; and since language is a system of internal differences never offering any stability of reference, always already deferred, the idea of subjectivity as a locus of identity or knowledge is problematized. In their essay "Theory Pedagogy Politics: The Crisis of 'The Subject' in the Humanities," Mas'ud Zavarzadeh and Donald Morton state that in the postmodern view the subject is less the instigator of meaning than "the effect of intersections of meaning generating signs" (5). It is within and through language that the subject constitutes themself, because it is language alone that establishes the concept of an ego. But since language is built on difference, consciousness of self only becomes possible if it is experienced by contrast (Zavarzadeh and Morton 5). Thus, difference becomes the basis of identity, but also prevents any positing of fixity since the arbitrary signs of language never have a one-to-one correspondence with any absolute referent. The subject is not the sign of man's timeless nature, but a network of connections and significations:

(post)modern critical theory does not conceptualize the subject as a stable entity but argues that the parameters of the subject vary according to the current discursive practices in any historical moment. In this view, the human does not possess a timeless essence, a consciousness that place him beyond historical and political practices; rather, he is considered to be produced by these practices or as an effect of these discourses. (Zavarzadeh and Morton 5)

Self or subjectivity is not so much a timeless human essence, then, but a verbal construct. Michel Foucault argues the same point in The Order of Things, emphasizing that man is a 
recent invention, that consciousness is a by-product of the historical codifications of knowledge, and that "man" will likely disappear when that knowledge finds another form:

If those arrangements were to disappear as they appeared, if some event of which we can at the moment do no more than sense the possibility--without knowing either what its form will be or what it promises--were to cause them to crumble, as the ground of Classical thought did, at the end of the eighteenth century, then one can certainly wager that man would be erased, like a face drawn in sand at the edge of the sea. (Foucault 387)

Subjectivity is the product of language, in other words, and the development of consciousness into present forms is due to the emergence of particular linguistic patterns. The continual change of linguistic patterns, as well, may give rise to new forms of consciousness.

The association Foucault makes between language change and modes of subjectivity is an important one for poststructuralism. Because consciousness and subjectivity are "no longer a privileged source of order," states John Johnston, they have "been pre-empted by a more direct concern with language as a field of endless articulations" (140-141). Language and writing, in the postmodern, are a site where rather than the timeless essence of the self is discovered or revealed, subjectivity endlessly takes its forms in the rearticulations of writing itself. "Hence the conventions, assumptions and strategies of writing as such are much more important for the postmodernist, for whom language is no longer the idealistic and expressive medium of a re-existing consciousness or ego, but a material part of the world ..." (Johnston 141). Instead of depth, writing and language proliferate alternative surfaces and meanings, intertextual relations between texts, a flatness or depthlessness, a superficiality that becomes associated with "the fragmentation and dissolution of the subject, with, in other words, the "death" of the autonomous bourgeois individual" (Johnston 145). Thus, the discussion of the nature of subjectivity takes on wider significance as one becomes aware of the postmodern revision of historical distinctions. It is as if in destablizing the notion of the individual consciousness, 
poststructuralism also weakens those codifications of knowledge that Foucault suggests accompany the existence of this consciousness. As the notion of a persisting consciousness outside the material of language is undermined, so are those are those divisions of knowledge that reflect the existence of that form of subjectivity.

Ashbery's poem is particularly interesting in that it not only shares postmodernism's preoccupation with language as a site for the construction of meaning, but also because it seeks to undermine those very same constructions. The poem is successful because it not only explores itself as a construction within language, demonstrating its dependence on the processes of deferral and displacement, but also because it passes between the ideal distinctions of theory and poetry. The poem, because it undermines distinctions in order to show their arbitrary construction within a language that is always literary and figurative, is able to offer an alternative discourse that passes between theory and poetry. It acts as a passing theory, negotiating the historically opposed discourses of poetry and theory, erasing the barriers that obstruct interaction between them. Ashbery's poetry passes between the distinction of theory and poetry, says Charles Altieri, by bringing them together in order to move beyond the limits of each. As Altieri states:

All the theoretical instruments seem to agree that our culture must develop versions of agency that neither return to romantic notions of a deep-buried and alienated self desperate for expression nor replace that inwardness by reducing subjectivity to subjection within linguistic and social codes. Yet, as I have argued on other occasions, contemporary theory has become so dependent of poststructural concepts that it lacks the resources to develop an adequate third choice on this issue.... Our poets do better ... because they envision subjective agency in positive terms as a specific mode of dynamic intentionality inseparable from how we inhabit the sentences we speak. Developing their own way ... these poets offer a perspective that frees us from having to locate subjectivity in any specific image or narrative account. For they realize that such projections entail chains of significations and displacements that keep deferring that self until it can only appear a deeply buried and alienated principle. ("Motives in Metaphor" 215) 
While theory is useful, Altieri argues, poetry is able to offer a powerful alternative to theoretical argument because of its ability to provide richer, more subtle and considerably more developed thinking than that provided by prevailing theoretical stances. Because of its awareness of how sentences form ideas, its understanding of the linguistic nature of the construction of meaning, poetry is able to resist framing its own arguments as static entities. In this way contemporary poets are able to mediate the romantic view of the self as beyond language and the contemporary theoretical view of the self as only a product of social codes and formations. Ashbery brings these poetic and theoretical discourses together to address the limits of both.

Ashbery's poem does not so much begin as it continues. Taking or "mirroring" another reflective portrait, Ashbery's poem immediately opens up the postmodern possibilities with its title: "Self-Portrait In A Convex Mirror" is the title both of this poem and of Parmigianino's Mannerist self-portrait. The continuing rather than beginning is compounded by the poem's use of the epic device of In Medias Res, the starting in the middle of things. Already one senses that the poem has set in motion or furthered an always already happening motion of representation. That is, by problematizing the notion of beginning through the "mirroring" title and the In Medias Res, Ashbery does not clearly distinguish between the portrait and the poem, between himself and Parmigianino, between artist and poet. The reflective surface created by the title and the positing of a similarity of artist and poet in the "As" also makes it difficult to determine who the author is here: Parmigianino or Ashbery? Not distinguishing, then, or making such distinctions as author/audience more difficult to talk about with certainty, becomes a means of opening up representation, representation which works not as an expression of the transcendental or a revealed essence or truth, but of itself. That is, representation does not indicate anything other than itself, it does not point to anything outside of itself. There is nothing to be expressed in art but art, the material instead of the spiritual: 
As Parmigianino did it, the right hand

Bigger than the head, thrust at the viewer

And swerving easily away, as though to protect

What it advertises. A few leaded panes, old beams,

Fur, pleated muslin, a coral ring run together

In a movement supporting the face, which swims

Toward and away like the hand

Except that it is in repose. It is what is

Sequestered. ...

("Self-Portrait" 68)

The distortion of the representation here, "The right hand / Bigger than the head," is like that of John Barth's Lost in the Funhouse, where the funhouse mirror of representation distorts and calls attention to itself in the process. The foregrounding, as well, of the tool of artifice--the right hand--is particularly interesting. It emphasizes not only the distortion of artifice, calling attention to itself, but also suggests the power of representation's own processes over authorial intention. Rather than describing any truthful or accurate depiction of the subject of representation, artifice is a copy of a copy, a simulacrum, a reflection of a reflection; and while an artist intends one thing, the mechanisms of artifice, the "distortions" of the funhouse mirror, circumvent such intentions. This always happens, says the poet. It is the way things get done:

Seduced by flowers,

Explicit pleasures, he blames himself (though

Secretly satisfied with the result), imagining

He had a say in the matter and exercised

An option of which he was hardly conscious,

Unaware that necessity circumvents such resolutions.

So as to create something new

For itself, that there is no other way,

That the history of creation proceeds according to

Stringent laws, and that things

Do get done in this way, but never the things

We set out to accomplish and wanted so desperately

To see come into being. Parmigianino

Must have realized this as he worked at his

Life-obstructing task.

("Self-Portrait" 80)

Thus, while Parmigianino can be seen as intending to paint his "self," what he ends up painting, as the poet suggests, is the manner in which representation undoes such 
intentions. In painting the self, then, Parmigianino is not so much painting it as he is painting painting. As the poem says:

The glass chose to reflect what he saw

Which was enough for his purpose: his image

Glazed, embalmed, projected at a 180-degree angle.

The time of day or the density of the light

Adhering to the face keeps it

Lively and intact in a recurring wave

Of arrival. The soul establishes itself.

But how far can it swim out through the eyes

And still return safely to its nest? The surface

Of the mirror being convex, the distance increases

Significantly; that is, enough to make the point

That the soul is a captive, treated humanely, kept

In suspension, unable to advance much farther

Than your look intercepts the picture.

("Self-Portrait" 68-69)

Captive, embalmed, glazed, in suspension, sequestered, unable to advance much further, the soul is bound up within the artifice that it would like to protect us from seeing. That is, the soul is rendered in the artifice of these productions--the painting and the poem--and, as such, is a captive of them, an effect of them and not a rendering of any "timeless essence of human nature." Artifice can continue to evoke the soul's "lively and intact" nature but only at the price of advertising the artifice of its own descriptions of it--the "recurring wave." The painting, the poem says, measures the extent to which art can actually depict something like the "self." And residing as it does in the artifice of the work--contingent and tenuous, dependent upon others for its recreation and realization--the soul is nothing. It is a thing without a sentence and, hence, not a thing at all.

An integral part of this notion of representation as being representational of itself is that the ambivalence of the portrait prevents the positing of anything beyond itself. The painting/poem's subject is the artist himself, but given that any representation is only able to depict representation, the idea of being able to describe or render an account of the self outside the mediation of representation is undermined. In other words, what both Parmigianino and Ashbery posit is a view of representation that indicates only itself 
because even the most realistic intentions are not able to escape the deferral that takes place in artifice. What representation depicts, according to the mechanisms of the poem, is its nature as a surface phenomena and not a medium of expression for transcendence or contact with the divine or the timeless nature of man:

your eyes proclaim

That everything is surface. The surface is what's there

And nothing can exist except what's there.

There are no recesses in the room, only alcoves ....

("Self-Portrait" 70)

The view expressed here towards representation bears on language in much the same way. As the poet notes, language, being a system of representation, is also caught up in the same mechanisms and processes. This leads the poet to suggest that just as there is only surface, only representation, there is no other language to bring attention to this but the language we have. There is no meta-language to describe how language works:

And just as there are no words for the surface, that is,

No words to say what it really is, that it is not

Superficial but a visible core, then there is

No way out of the problem of pathos vs. experience.

("Self-Portrait" 70)

Since there is no other language to discuss language, without being caught up in the same processes that make the notion of talking about something outside language so tenuous, what we are left with is the way of telling:

But as the principle of each individual thing is

Hostile to, exists at the expense of all the others

As philosophers have often pointed out, at least

This thing, the mute, undivided present,

Has the justification of logic, which

In this instance isn't a bad thing

Or wouldn't be, if the way of telling

Didn't somehow intrude, twisting the end result

Into a caricature of itself.

("Self-Portrait" 80; italics added)

The way of telling defers the existence of the present. Telling intrudes upon it and twists it into something it isn't or wasn't before it got told. In other words, language, being a system whose materials are never fully present in themselves, but always already deferred, 
"dooms in advance" those efforts to secure a fixed and determined truth, transcendence, or essence. Language, however, as emphasized in the "linguistic turn," is no longer determined by criteria that measure its success by its ability to correspond with a single truth or essence.

Instead of lamenting this condition as one that continually removes us from ideals, Ashbery affirms this process of language as, paradoxically, the source of human creativity. As the poem says:

What should be the vacuum of a dream Becomes continually replete as the source of dreams Is being tapped so that this one dream May wax, flourish like a cabbage rose .... ("Self-Portrait" 73)

A system, whose tenuousness as a surface phenomena, with nothing within it which would correspond with a truth out there, is not exactly what one would prefer to construct descriptions of the world with. However, the poem tells us this is precisely what happens-and the poem, "this one dream," acts as embodiment of that principle. Supporting this point, the poem then returns to its citation of other texts and quotes a critical work on Parmigianino, stating that his Self-Portrait no longer produces an objective truth, but, as well, does not create a feeling of disharmony--as if truth were synonymous with harmony:

The forms retain

A strong measure of ideal beauty," because

Fed by our dreams, so inconsequential until one day

We notice the hole they left. Now their importance

If not their meaning is plain. They were to nourish

A dream which includes them all, as they are

Finally reversed in the accumulating mirror.

("Self-Portrait" 73)

It is the system of language, without any fixity or correspondence to a truth that would ground it in a one-to-one relationship with the thing it describes, that allows for the emergence of beauty. It is the lack, the absence in human sentences of a timeless "truth," that allows beauty to be created. It is the "vacuum" that is language, a system built on absences, that allows "dreams," the creative imagination, to fill in the blanks and create 
beauty. But these dreams, too, are holes--which we notice when we no longer hold to them, move on to other descriptions of the world and self, those too a "posture of a dream." The poem, thus, suggests its own cultural embeddedness, the sense that its own constructions are as contingent and context-bound as any, and that these, too, will come to be superseded at some point.

Since Parmigianino's work is ostensibly a "self" portrait, his intention to represent it is subject to the processes of representation that make such intentions tenuous and "distorted," as well as making the idea of self out to be a mere "vacuum of a dream." The self is empty and devoid of any inherent meaning, except that created for it by its audience and therefore subject to the whims and fancies of change over time. Hence, the self is never present in itself, but is always subject to the way such ideas are constructed by historical periods. But this impulse in Ashbery to show how the idea of the self is contingent and caught up in the processes of representation and reception is always preceded or accompanied by the need to insert the notion of the possibility of a subjectivity beyond the materiality of language. There is a lingering romanticism which longs for the inexpressible, for what lies beyond rhetoric--as if it were difficult to admit, even in the face of evidence to the contrary, that it is a simply another false dream:

And just as there are no words for the surface, that is, No words to say what it really is, that it is not Superficial but a visible core, then there is No way out of the problem of pathos vs. experience. ("Self-Portrait" 70)

As Ashbery tells it, the work expresses its inadequacies, its failure to achieve imaginary plenitude, its inability to offer a fully present account of the self.

there is in that gaze a combination Of tenderness, amusement and regret, so powerful In its restraint that one cannot look for long. The secret is too plain. The pity of it smarts, Makes hot tears spurt: that the soul is not a soul, Has no secret, is small and it fits Its hollow perfectly: its room, our moment of attention. That is the tune but there are no words. 
The words are only speculation

(From the Latin speculum, mirror):

They seek and cannot find the meaning of the music

We see only postures of the dream,

Riders of the motion that swings the face

Into view under evening skies, with no

False disarray as proof of authenticity.

("Self-Portrait" 69)

The soul is small, almost nonexistent--as far as its presence in the work goes--and is not even a soul. What the work represents is the obviousness of the lack of a secret: "that the soul is not a soul." It is not a secret, it is not anything other than the "hollow," "its room, our moment of attention" gives it. The soul is to the extent that it is given form in the work, to the extent that we engage and involve our attention as viewers or readers with it. But because the soul is nothing beyond its representation in the work, it offers no potential for being read as an idealized essence or source of meaning. This is the figure that the portrait attempts and fails, the tune with no words. Thus, with no sentence to describe it, no truth to its being or becoming, it goes on seeking words to say what meaning might be in the music. And the words we do have to describe the self in the portrait are simply "speculation"--contingent to the point that all we have are their cast-off shells, the empty signs of a de-idealized presence, the signs of signs, "postures of the dream."

There is always, however, the possibility of reading in the painting an intention to reach out through the painting to the viewer by way of the depiction of a "realistic" presence in the figure of the painting. It is a desire on the part of the subject of the painting to leave the world of artifice, to erase the distinction between art and life, to be present; but it is art, after all, and as such prevents such intentions:

it is life englobed.

One would like to stick one's hand out of the globe, but its dimension, What carries it, will not allow it.

("Self-Portrait" 69)

Thus, the ambivalence of the painting/poem "which swims / Toward and away like the hand / Except it is in repose," and which would like to be present but is not able to, 
reinforces the deferral of presence in representation; like the hand, the instrument of art(ifice), the face appears to have life, presence, given to it by the realistic form of this painting. But it is like the hand in its ambivalence, swimming toward and away at the same time, unsure of whether it is protecting or advertising its status as representation and therefore never fully present in itself. This ambivalence is also suggested by the unspecified pronominal "it" in the line "It is what is sequestered," which could refer to either the face and/or the hand. The painting/poem hovers in suspension, somewhere between head and hand, protecting and/or advertising, coming near and moving away, so that the only meaning it is able to impart to its viewer is its status as representation, as art.

The ambivalence apparent in the "Self-Portrait" is itself a sign of a broader anxiety in the poem concerning the materials and conditions of poetic representation. The deferral of a self-present figure of representation in the painting, which Ashbery reflects in the poem, not only suggests how the poem shares the poststructural milieu, but also indicates the conflicting impulses within this context that impinge on poetic representation. This is clear in Ashbery's positing throughout the poem of an area of mystery, a site beyond language that remains inexpressible but which exists side by side with the postmodern subversion of such possibilities:

Love once

Tipped the scales but now is shadowed, invisible, Though mysteriously present, around somewhere.

But we know it cannot be sandwiched

Between two adjacent moments, that its windings

Lead nowhere except to further tributaries

And that these empty themselves into a vague

Sense of something that can never be known

Even though it seems likely that each of us

Knows what it is and is capable of

Communicating it to each other.

("Self-Portrait" 77)

Though there is an aura of mystery, a landscape somehow invested with meaning, this ineffable is deflated by the knowledge that each of us can describe it to the other, reveal it and put it into language. In Ashbery, then, the notion of a mysterious realm beyond 
language is still very much a part of poetic representation. However, this aura and mystery is constantly undercut by the view of language and representation as a phenomena that multiplies surfaces, indicating not the inexpressible but the mechanisms of representation and language themselves. As Anita Sokolsky puts it, these two impulses are always present in Ashbery:

[Each time he] recognizes the portrait's pronouncement that there is only surface he reinserts a yearning for the ineffable, for the unsayable. After recognizing that "the soul is not a soul," he says "That is the tune, but there are no words"; as though the words "the soul is not a soul" need to posit the illusion that the language of disillusion can only approximate an impalpable, greater meaning. ... These lines deliberately reinsert the opposition between the pathos of the unsayable, with its hidden reserve of meaning, and experience's implicit recognition that there is no more to be said than itself. The narcissistic dynamic which posits the greater and unimaginable capacity for gratification in the other emerges in the poem whenever Ashbery reinserts a nostalgic desire for mystery, for the inexpressible nature of experience: the pathos of imagining that words are inadequate to their capacity for meaning. Thus, Francesco's portrait enacts for Ashbery the dynamic between, on one hand, a recognition of the illusion of hidden meaning, and, on the other, the perpetual need to invest that moment of recognition with a sense of pathos. (240-241)

Thus, the anxiety of the poem is seen in its inability or deliberate refusal to decide between the postmodern critique of the illusion of hidden meaning (all is on the surface) or the romantic view of language as inadequate for the expression of contact with the divine. It is because of this ambivalence, perhaps, that the poet brings together theory and poetry. While maintaining the tension between the postmodern and the romantic views of language, the poet is able to create a "passing theory" between these two historically and critically antithetical discourses. The postmodern poet, in other words, needs both discourses in order see over the limits of each. Poetry and theory, both aware of the linguistic construction of consciousness, the poststructural denial of a metalanguage, come together in Ashbery for the purpose of limiting the effects of a transcendental romanticism and for 
the purpose of suggesting our continued need for something more than self-referential mirror games. As the poem puts it:

There is no other way, and those assholes

Who would confuse everything with their mirror games

Which seem to multiply stakes and possibilities, or

At least confuse issues by means of an investing

Aura that would corrode the architecture

Of the whole in a haze of suppressed mockery,

Are beside the point. They are out of the game,

Which doesn't exist until they are out of it.

("Self-Portrait" 79-80)

What the postmodern context and poststructural concepts offer Ashbery, then, are a means with which to invest and corrode his own poetic project at the same time. Ashbery's investing and corroding poem is what has been called a "self-consuming artifact," a text that while putting itself together, takes itself apart at the same time. Constructing itself from the residues of meaning that the poet finds in Parmigianino's painting, the poem cannot be said to be either clearly contiguous or whole in and of itself, nor clearly original with the poet--particularly since it makes such a point of constructing itself from the discourse of others. "Self-Portrait" not only uses quotations and parts of speech from other critics in order to make itself, but internalizes intertextuality and reception theory as part of its own creative process:

A peculiar slant

Of memory that intrudes on the dreaming model

In the silence of the studio as he considers

Lifting the pencil to the self-portrait.

How many people came and stayed a certain time, Uttered light or dark speech that became part of you

Like light behind windblown fog and sand,

Filtered and influenced by it, until no part

Remains that is surely you.

("Self-Portrait" 71)

Ashbery's intrusion of his own present circumstances and exigencies become linked with the painter's creative act--they are virtually indistinguishable, they fuse together in the present of the poem. 
Furthermore, the discussion of the painting's reception, by Pope Clement, suggests the intertextual creation of any text: that is, the view that a work of art is not so much the result of itself, but of what others say about it, how it is received by audiences, and how it is critically interpreted and responded to. Ashbery's poem is well aware of this process, how other people talking and writing about Parmigianino, even Ashbery himself for that matter, come to constitute what that work is. It is not so much the work itself which creates its meanings, says the poem, but what others say and have said about it. It is the accumulation of words and other images that refer to the work which come to constitute its meaning. Constructing itself as intertext and critical reflection on the processes of representation, Ashbery's poem resists stability and fixity. It is laid out over a terrain of references and citations and quotations in such a way that gathering them into unity does not establish unity but, instead, plurality and discontinuity. Putting his text together in a parasitic or derivative manner, the poet intimates that representation proceeds in this way-"This always / Happens, as in the game where / A whispered phrase passed around the room / Ends up as something completely different" (80)--and never allows access to what might be called "original." In this way, each part comes to be a part of the poem, but in a fashion that resists the attribution of an originary or idealized sense to it:

The hand holds no chalk

And each part of the whole falls off

And cannot know it knew, except

Here and there, in cold pockets

Of remembrance, whispers out of time.

("Self-Portrait" 83)

As the poem puts itself together, then, from the bits and pieces of discourse available to it, speaking through these, it avoids reduction to a single clear determinate principle or meaning. In this way, Ashbery retains a sense of mystery and aura, the pathos of something beyond language, since "each part" cannot be reduced to an isolated and uncorrupted status as origin. However, Ashbery also retains the postmodern critical view that works against this ideal of the inexpressible by emphasizing language as a surface 
phenomena of signs, not as deep structural meaning or an inadequate medium for the expression of a transcendent ideal or essence.

Passing between the postmodern/poststructural views of language and representation and the romantic pathos of a self that resists being given shape, Ashbery's poem not only responds to the opposition between theory and poetry but to the contemporary revision of this difference. By addressing the poststructuralist notions of subjectivity and bringing them into contact with a residual romanticism that posits an idealized version of self as beyond representation, Ashbery indicates the limits of both discourses. He creates a poem that speculates on its own ability to construct a speaking, writing, knowing subject and, thus, demonstrates the contingent nature of this creation called the self. Writing and reflecting become a process that work in conjunction with each other--building up and tearing down simultaneously. The self-consuming nature of this process-as-poem gives us the limits of the view of self beyond expression and the limits of a self that is only the effect of cultural and historical significations, since both needs and impulses remain but cancel each other out. It is in this way that Ashbery implicates the conventions of both versions of subjectivity and rejects both. As he says of the convention of realism in Parmigianino:

Aping naturalness may be the first step

But it is the first step only, and often

Remains a frozen gesture of welcome etched

On the air materializing behind it,

A convention. And we have really

No time for these, except to use them

For kindling. The sooner they are burnt up

The better for the roles we have to play.

("Self-Portrait" 82)

As these conventions are burnt up in Ashbery's poem, we are left holding something that slips between our fingers like sand--"the 'it was all a dream' / Syndrome, though the 'all' tells tersely / Enough how it wasn't" ("Self-Portrait" 82)--and like the "waking dream" the poem has made and unmade itself in a process that does not so much reconcile oppositions 
like theory and poetry but passes between the criteria for either. In this way, then, Ashbery not only suggests the historical limits of theoretical and poetic models, but also implies that their limits are our opportunity. In burning up the conventions of these discourses, seeing them as the conventions they are, an alternative may emerge. 


\section{Chapter Four}

\section{Revising Literary Traditions: Ashbery's (Dis)engagement with Romanticism and Modernism}

While a great deal of critical examination of "Self-Portrait" has concerned itself with the philosophical, theoretical, and aesthetic formulations operating within it, less attention has been paid to how the poem addresses and engages with its own specific cultural heritage. Discussion of the concepts and ideas that make up the poem's dynamics is valuable; but without a reading of "Self-Portrait" as a site for the intermingling and transformation of aesthetic traditions its character is overlooked. This is so because the poem's engagement with issues that stem from romantic and modernist traditions, the manner in which it speaks through these issues and shapes them to postmodern ends, demands a reading that does not posit the poem as simply "postmodern," "romantic," or "modernist." To pigeon-hole the poem as categorically stable is to misrepresent its explicit erasure of hard and fast distinctions, especially as they affect the poem's relationship to its aesthetic past.

Although there are differing views as to what constitutes the categories of modernism and romanticism, there are several impulses generally accepted as characteristic. Among those that M.H. Abrams (115-117) identifies as constitutive of romanticism are: (1) an attitude favoring innovation over traditionalism in the materials, forms, and style of literature; (2) nature becoming a main focus of poetry, but most often used to prompt a meditation on human problems; (3) literature developing not so much about "men" in action as about a writer's particular feelings; (4) literature coming to be seen as spontaneous, 
"natural," and, thus, the opposite of artful composition; (5) poetry depicting the poet themself as the subject of the poem. Quite often that depiction, too, is of an outcast or isolated and individual figure; (6) the highest art for the romantics consisted in an endeavor beyond finite human possibility. Thus, a preference for the imperfect, which depicted the failure of the artist and demonstrates the grandeur of his aim.

Surprisingly, "Self-Portrait" falls within the range of these characteristics, although in a highly refracted fashion. The poem's attitude is most assuredly innovative towards issues of material, form, and style, but, here again, it is typically ambivalent. Taking a work of "high" art as its ostensible subject, for example, Parmigianino's first "SelfPortrait" is not exactly an embracing of the "common." The poem's style retains the romantic imperative to use the real language of men, but it pushes the boundaries of sense in its obstrusiveness and vagueness, its indefiniteness and duplicity of reference. Its form, long and meandering, seems a middle ground between radical disjunction and formalism.

The other characteristics Abrams identifies are also part of the poem, in their modified versions, and serve to amplify Ashbery's revision of the romantic tradition. The poem is obviously self-referential, obviously taking as its subject the nature of a self in the midst of contemplating a work of art. Moreover, it often makes the vicissitudes of contemplation part of itself:

The balloon pops, the attention

Turns dully away. Clouds

In the puddle stir up into sawtoothed fragments.

I think of the friends

Who came to see me, of what yesterday

Was like.

("Self-Portrait" 71)

This, too, is a "spontaneous" emotion, a recollection of an experience of perception recorded by the poet. For Ashbery, however, the sense of the poem as a recording of a fleeting moment of perception is always "artful." It is always part of the processes of 
artifice, always shaped and given form through art, always mediated by the poem. There is no other way:

But as the principle of each individual thing is Hostile to, exists at the expense of all the others As philosophers have often pointed out, at least This thing, the mute, undivided present, Has the justification of logic, which In this instance isn't a bad thing Or wouldn't be, if the way of telling Didn't somehow intrude, twisting the end result Into a caricature of itself. This always Happens, as in the game where A whispered phrase passed around the room Ends up as something completely different. It is the principle that makes works of art so unlike What the artist intended. Often he finds He has omitted the thing he started out to say In the first place.

(“Self-Portrait" 80)

It is significant, here, that rather than taking nature as its ostensible starting point for a meditation on "the nature of man," Ashbery's poem takes "art" as the starting point for a meditation on the nature of representing subjectivity. Thus, maintaining the romantic tradition of depicting the state of emotions of the poet, making the poet the subject of the poem, Ashbery turns this heritage on its head by evoking and then disassembling it, showing how the valorization of the individual poet is ultimately shaped by the conventions used to depict his self: "Since it is a metaphor / Made to include us, we are a part of it and / Can live in it as in fact we have done ..." ("Self-Portrait" 76). The effect of Ashbery's inversion of romanticism is to undercut and subvert from within the conventions of a humanistic, essentialized, mythic view of subjectivity--particularly the romantic idealization of the poet. We see this any number of times through out the poem where, rather than perceiving some human "truth," the poet is continually confronted by his own "otherness":

What is novel is the extreme care in rendering

The velleities of the rounded reflecting surface

(It is the first mirror portrait),

So that you could be fooled for a moment

Before you realize the reflection

Isn't yours. You feel then like one of those 
Hoffman characters who have been deprived

Of a reflection....

("Self-Portrait" 74)

There is also the very similar passage:

This otherness, this

"Not-being-us" is all there is to look at

In the mirror, though no one can say

How it came to be this way.

("Self-Portrait" 81)

It is worth remarking, though, that as much as passages like these seem to call into question the poet's ability to posit a self outside of poetic or aesthetic conventions, they also share romanticism's belief in the inadequacy of language. As Abrams points out, the romantics believed in humanity's "unquenchable aspirations beyond its assigned limits" (117). Romanticism sought after the absolute, the ideal, the infinite, the inaccessible. This is, in effect, the postulation of a realm beyond human expression, a realm that remains yearned for but never achieved. It provides the romantics with a source of energy that motivates their "spontaneous overflow of emotion" and becomes a source of mystery within their work. It is much the same gesture that occurs in Ashbery's work, setting up the self as "other," as some thing that always remains unknowable.

If we compare Ashbery's romanticism with that of Walt Whitman's, the differences between them will indicate the character of Ashbery's engagement with a residual romanticism. Harold Bloom has often remarked on the genealogy that stems from Whitman, by way of Wallace Stevens, to Ashbery. As Bloom says, like his "master" Stevens, Ashbery is essentially a ruminative poet, “ turning a few subjects over and over, knowing always that what counts is the mythology of self, blotched out beyond unblotching” (7). But it is Whitman who remains Ashbery's largest ancestor, providing the basis of a conscious manipulation and exaggeration of subjectivity for American poets (Bloom 7). When Whitman writes that "I celebrate myself, / And what I assume you shall 
assume, / For every atom belonging to me as good belongs to you" (Whitman 25) he initiates the contemplation of poetic self that American romanticism has come to be synonymous. "I loafe and invite my soul, / I lean and loafe at my ease .... observing a spear of grass," says Whitman (25), opening the door towards a contemplation of self in American poetry. It is also significant that the subjectivity described here is quite similar to the one in "Self-Portrait," in that it is less concerned with separating itself from other subjectivities than in highlighting the exchanges and interactions that take place between them. Whitman's celebration of self, for its own sake, is also an invitation extended to the reader to partake in the experience of the expansive self-consciousness, not terribly dissimilar from the contact the poet makes with Parmigianino in "Self-Portrait." That is, as Whitman extends an invitation to the reader to contemplate their own or Whitman's self, Parmigianino's portrait similarly extends an invitation to the poet to contemplate the self of painter and poet which come to commingle. Here, for instance, the poet notes the experience of looking at the portrait, how his attention has dissipated; but as the poem progresses, it becomes clear that the "he" could either be Parmigianino or the poet:

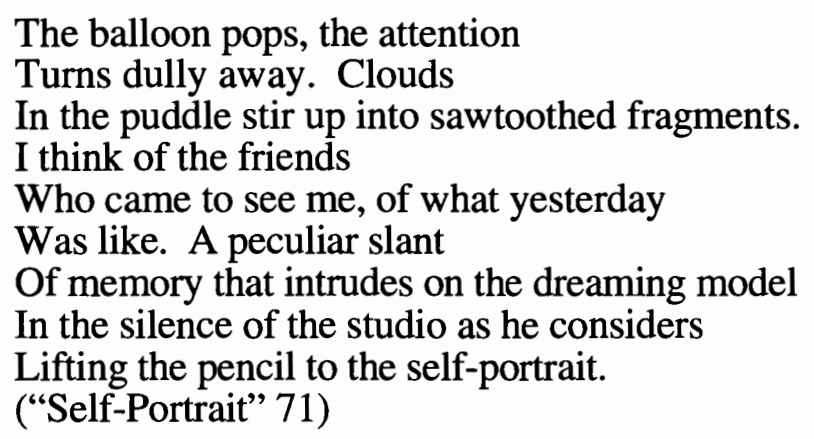

As the subjectivity moves through this passage, what is remarkable is the shift between the two sentences. The first sentence, noting the dissolution of an attentive contemplation of the portrait in a first-person account, is then modified in the second sentence to denote a third person perspective. It moves from an "I" to a "he," as if the poet were suddenly receding before himself as he continues to write, no longer describing the experience of the portrait but the experience of a subjectivity--the "he"--other than his own that is 
constructing a self-portrait. Characteristically, this could be the poet describing himself in third-person and/or Parmigianino in first-person.

The difficulty of distinguishing between the poet and the painter in "Self-Portrait" has its counterpart in "Song of Myself" in those long sections where the poet's allencompassing self flies "the flight of the fluid and swallowing soul" (Whitman 61). Traversing the difference between his self, the selves of others and the physical world, Whitman's soul is part of everything and everything is a part of him:

I visit the orchards of God and look at the spheric product, And look at quintillions ripened, and look at quintillions green.

I fly the flight of the fluid and swallowing soul, My course runs below the soundings of plummets.

I help myself to material and immaterial, No guard can shut me off, no law prevent me.

(Whitman 60-61).

This "transcendental power" of the soul which enables it to be in contact with all things allows Whitman, as a poet, to mingle and conjoin irreconcilable aspects of the world within a single, all-encompassing poem. It allows him to create a self from the various voices of experience. As the poet says, "And these tend inward to me, and I tend outward to them, / And as such as it is to be of these more or less I am, / And of these one and all I weave the song of myself" (Whitman 40):

Through me many long dumb voices,

Voices of the interminable generations of slaves,

Voices of prostitutes and of deformed persons,

Voices of the diseased and despairing, and of thieves and dwarfs,

Voices of cycles of preparation and accretion,

And of the threads that connect the stars--and of wombs, and of the fatherstuff,

And of the rights of them the others are down upon,

Of the trivial and flat and foolish and despised,

Of fog in the air and beetles rolling balls of dung.

Through me forbidden voices,

Voices of sexes and lusts .... voices veiled, and I remove the veil, Voices indecent by me clarified and transfigured.

(Whitman 48) 
In constructing a self from a multitude of voices, a self that is able to encompass all, able to traverse the boundaries of space and time, Whitman constructs a self that believes itself able to reveal the deeper logic and meaning behind the multitude of differences that make up the world. Because it is part of all things, subjectivity in this poem sees itself as having access to what lies beyond appearances; each person, each animal and thing in "Song of Myself" is part of a larger whole, each thing only a part of a larger order it can only see a part of. As Whitman says, "A few quadrillions of eras, a few octillions of cubic leagues, do not / hazard the span or make it impatient, / They are but parts . . . any thing is but a part" (Whitman 79). Quite often, though, the poetic reach toward that larger order comes up against the impulse to obscure it, to place the larger order behind all the seeming disparity beyond expression, outside the capabilities of a limited human knowledge:

My voice goes after what my eyes cannot reach,

With the twirl of my tongue I encompass worlds and volumes of worlds.

Speech is the twin of my vision .... it is unequal to measure itself.

It provokes me forever,

It says sarcastically, Walt, you understand enough . . . why don't you let it out then?

Come now I will not be tantalized . . . . you conceive too much of articulation.

(Whitman 50-51)

Whitman's promotion of his abilities to "unscrew the doors from their jambs," to "wash the gum" from our eyes, to remove the veil, also insists upon an area, a realm, some knowledge that escapes his will or ability to express:

There is that in me ... I do not know what it is . . . but I know it is in me.

Wrenched and sweaty .... calm and cool then my body becomes; I sleep .... I sleep long.

I do not know it .... it is without name .... it is a word unsaid, It is not in any dictionary or utterance or symbol.

Something it swings on more than the earth I swing on, 
To it the creation is the friend whose embracing awakes me.

Perhaps I might tell more . . . O Outlines! I plead for my brothers and sisters.

Do you see $\mathrm{O}$ my brothers and sisters?

It is not chaos or death .... it is form and union and plan . . . it is eternal life .... it is happiness.

(Whitman 84-85)

This is the essential romantic dilemma, believing the imagination capable of all things while needing to retain a source of energy and mystery that motivates works of the imagination. That is, if the imagination were capable of revealing all there would only need to be one representative work that told it all--all else would be pointless and redundant. What else would need to be said if one were capable of saying it all?

Whitman and Ashbery both wrestle with this romantic situation. But whereas Whitman believes himself capable of suggesting the presence of a truth, albeit a truth alternately knowable and unknowable, Ashbery, on the other hand, distances himself from the rhetorical grandeur of Whitman's all-encompassing romanticism. Ashbery stands between being able to represent what the imagination is capable of and the sense that the imagination is all there is to say. As Ashbery suggests in "Self-Portrait":

You will stay on, restive, serene in

Your gesture which is neither embrace nor warning

But which holds something of both in pure

Affirmation that doesn't affirm anything.

("Self-Portrait" 70)

The poet, observing the portrait, sees something in it that mirrors his own project, his own purpose in relation to the dilemma he has inherited from the past. The only way to deal with this dilemma is to see it as present and absent at the same time or, as it is put here, an affirmation that doesn't affirm anything. It is an in-between gesture, an ambivalence that hesitates between at least two possibilities and unsure of which way to proceed. This is the situation Ashbery's poem is confronted with: how to proceed in light of what possibilities 
remain. It is the same situation that the poet ultimately finds tiring in the portrait (and his own poem, perhaps), but which might contain new possibilities:

If they are to become classics

They must decide which side they are on.

Their reticence has undermined

The urban scenery, made its ambiguities

Look willful and tired, the games of an old man.

What we need now is this unlikely

Challenger pounding on the gates of an amazed

Castle. Your argument, Francesco,

Had begun to grow stale as no answer

Or answers were forthcoming. If it dissolves now

Into dust, that only means its time had come

Some time ago, but look now, and listen:

It may be that another life is stocked there

In recesses no one knew of; that it,

Not we are the change; that we are in fact it ....

("Self-Portrait" 76)

It is as if the poet were suggesting that the ambivalence, the ambiguity that is to be found in the portrait, is stale and unsuited to our present needs; but he also makes it clear that perhaps within this ambivalence lies another possibility. Typically, though, the poet does not allow the possibility to emerge into any transcendental or sublime ideal--it remains only a possibility etched in the air:

Of course some things Are possible, it knows, but it doesn't know

Which ones. Some day we will try

To do as many things as are possible

And perhaps we shall succeed at a handful

Of them, but this will not have anything

To do with what is promised today ....

("Self-Portrait" 72)

Confronting the in-betweenness of the tradition he has inherited, Ashbery in "SelfPortrait" turns the sublime and transcendental moments to be found in American poets like Whitman on their heads, inverts them in a way that drains them of their privileged moments of vision. In order to do this, however, Ashbery must work within the rhetoric of idealism, suggesting in much the same way Whitman does, the power of the imagination. Although one can see this gesture growing out of Whitman himself, it is Ashbery's 
foregrounding of both the possibility of the imagination and its limits within tradition and convention that distances him from a Whitmanian faith. As Bloom states, the difficulty for Ashbery is "how to construct something upon which to rejoice when you are the heir of this tradition, yet reject both privileged moments of vision and any privileged heightenings of rhetoric in the deliberately subdued and even tone of your work":

For Ashbery, the privileged moments, like their images, are on the dump, and he wants to purify them by clearly placing them there. Say of what you see in the dark, Stevens urges, that it is this or that it is that, but do not use the rotted names. Use the rotted names, Ashbery urges, but cleanse them by seeing that you cannot be apart from them, and are partly redeemed by consciously suffering with them. (Bloom 65)

In exactly this way, then, Ashbery both affirms and doesn't affirm the romantic tradition and the rhetorical possibilities he inherits from it. 
As strongly as Ashbery grapples with the inheritance of the romantic tradition, the form of his engagement is quite modernist. That is, the manner in which Ashbery inhabits the forms of the past in order to empty them of their privileged moments is a modernist strategy, used to highlight the incompatibility of those aesthetic forms with our experiential lives. As Abrams points out, the modernist revolt against traditional literary forms and subjects that took place after World War I questioned the coherent and stable world those forms presupposed (109). The modernists, concerned about the immense discrepancy between the aesthetic order of tradition and the chaos they found themselves living within, undertook experiments with new forms and styles that often took the form of radical disjunction and disruption. Within this aesthetic disorder the audience was left to contemplate the various parts and to work towards inventing or discovering the connections that could reveal order and plan. This modification, however, for all its disturbances of order, simply replaces one order with another, reinscribes it in the form of disorder meant to be plumbed for meaning and significance. Ashbery, similarly, disturbs conventional order, disrupts the conventional reading experience, but instead of suggesting an alternative order he flattens the possibility of its emergence within his neutralilzed sentences and logic.

Typically, Ashbery confronts the aesthetic past and the privileged moments of insight it offers, but while there is a temptation to posit the possibility of order and meaning there always remains something that must be held at a distance:

for,

Though only exercise or tactic, it carries

The momentum of a conviction that had been building.

Mere forgetfulness cannot remove it

Nor wishing bring it back, as long as it remains

The white precipitate of its dream 
In the climate of sighs flung across our world, A cloth over a birdcage.

(“Self-Portrait” 77)

The conviction in possibilities of realization, of epiphany, of meaning, is confronted by the poet, but this certainty remains only an "exercise or tactic" never a clearly discernible or stable order or meaning. However, it is a possibility that no matter how distant or how skeptical the poet might be of it, it remains hovering, "mysteriously present, around somewhere" ("Self-Portrait" 77). Simple forgetfulness cannot make it disappear and wishing does nothing to bring it any closer. It is a mirage that is still with us, but only a precipitate, a derived product or result and not the thing itself. Ashbery, characteristically, gives us not only the possibility of order or meaning as a "precipitate," but goes on to obscure or bury that possibility in a compound of images and references; not only is the possibility of transcendent meaning impossible to forget and to bring back, but it remains so as long as it is not the thing itself, in an atmosphere that longs for it, that believes it remains to be revealed. Caught between not being able to forget it and not being able to grasp it, the poet remains in a disembodied, neutral space. His "thought-associations," compared to those epiphanous moments of the past, are gray and empty:

The fertile

Thought-associations that until now came

So easily, appear no more, or rarely. Their

Colorings are less intense, washed out

By autumn rains and winds, spoiled, muddied,

Given back to you because they are worthless.

("Self-Portrait" 81)

Devoid of the potential offered by modernism of an alternative order emerging from the imagination, Ashbery, working within the disruptions and dislocations of meaning the modernists are synonymous with, revises the modernist alternative to suggest its emptiness:

\section{Each person}

Has one big theory to explain the universe

But it doesn't tell the whole story

And in the end it is what is outside him 
That matters, to him and especially to us

Who have been given no help whatever

In decoding our own man-size quotient and must rely

On second-hand knowledge. Yet I know

That no one else's taste is going to be

Any help, and might as well be ignored.

("Self-Portrait" 81-82)

The universal answers, the poet suggests, simply do not explain the "whole story," no matter how complete they take themselves to be. We do not even understand ourselves, "our own man-size quotient" of the universe, and we must come to accept that we can only glimpse partial and incomplete answers--“second-hand knowledge."

Ashbery's refraction of the aesthetic past is also apparent in his adaptation of inherited forms to suit postmodernist impulses. Using the long poem with a lyrical emphasis, Ashbery's poem undermines distinctions between the lyric's short, introspective insights and the epic's length and breadth of scope. In traditional fashion, the poem accepts as its epic quest the contemporary search for self; but it shapes that quest with the lyric's concern for personal expression into a pursuit that yields only incomplete and transitory moments that are soon lost again. Modernist in its hybridization of the lyrical impulse within the proportions of the long or epic poem, Ashbery is also postmodernist in denying the emergence of new forms of perception from this generic mutation.

Describing "Self-Portrait" as long for "our damaged attention spans these days," Harold Bloom states that the poem is a revision of Whitman's "Song of Myself," a poem often identified as an American epic (115). While not explicitly calling "Self-Portrait" an epic, Bloom's discussion of its revision of the earlier poem suggests that the scope of Ashbery's poem is similarly large--by contemporary standards, anyway. More clearly "epic," however, is the poem's inner form, its subject. This distinction between inner and outer form of the epic is an important characteristic of contemporary versions of epic poetry, according to Thomas Vogler's Preludes To Vision:

First, the genre has most often been treated in formal and structural terms (outer form), and this is precisely 
the approach that is least likely to lead us to the nature of the modern mode of epic. The second reason is more complex, for the inner form of epic has remained essentially the same, while the problems of that inner form have changed, and changed in a qualitative rather than merely quantitative fashion. (5)

Putting it in the most humanistic terms, Vogler's view of epic seeks to remain outside of the differences of inner and outer form by seeing as constant the one feature he sees as common throughout: that epics are "poems of man in the fullest sense, facing the ultimate challenges of his time, responding with the fullest energy and endurance of his faculties, and achieving some kind of victory over the circumstances that constitute a challenge to his society's continued existence" (6). Attempts at formulating differences between epic and other genres are difficult if not impossible if they overlook this common feature, says Vogler (6). "The trouble with an attempt to formulate the inner form of epic in a few words is that any description of the epic on a highly general level will also sound like a description of tragedy" (Vogler 6).

Vogler finds it more useful to focus upon the changes in the consciousness of "man" that manifest themselves in the modern epic. Since "man" changes over time, so does "his" poetry. Instead of attempting a definition of the specific elements of the inner form of epic, Vogler sees it as that genre wherein "man" confronts the challenges of "his" time. Thus, rather than laying out particular formal structures and features in order to define the epic, Vogler holds that what remains constant as "epic subject matter" is its location as a poetic site for the major struggles and dilemmas of different cultures and periods. Dependent upon the cultural context of each age and period, the nature of these challenges changes and, consequently, the nature of epic subjects changes:

Although this common denominator of all poems that we call epic is the same, the factors that produce a true epic can and do change radically. What changes is the poet's conception of man, and perhaps even the very nature of man as his relation to his world changes. (Vogler 6) 
The difficulty, then, both in creating and recognizing a modern epic, is that our culture does not provide the same sorts of materials which earlier epic poets worked with. "There is no common ideology, no vital, central source for universally acceptable concepts of authority and value," says Vogler (8):

In the absence of an accepted spiritual orientation of the collective consciousness and of a shared sense of value, the nature of achievable epic poetry must change; but the possibility of epic poetry does not necessarily disappear. The nature of the epic challenge to man becomes that of finding, rather than preserving, an acceptable collective ideology of some kind. ... Before a poet can do this, he must have a firm faith in the power of poetic vision as a mode of finding ultimate truths about the nature of man; he must have the highest possible estimate of the powers of the poetic imagination and complete faith in that estimate. (Vogler 9)

Vogler's sense, here, of the humanistic nature of the epic enterprise, his faith in a poet's "finding ultimate truths about the nature of man," for all its awareness of the determined construction of "consciousness," still predicates a belief in a subject called "man" that searches unceasingly for transhistorical "ultimate truths." This may assist the critic in assessing older forms of epic, but it does not help us with Ashbery because of his skepticism towards the "whole story." What is valuable in Vogler's perspective, though, is that as "man" changes, so does epic poetry. More specifically, what is useful in Vogler's discussion is how he sees modern epic poetry as more overtly concerned with itself, with its own structures and possibilities, as a way of discovering different ways of knowing the world. Faced with the impossibility and absence of widely accepted collective beliefs as the basis on which to write, contemporary poets must turn to the most basic epistemological problems of vision and perception, dwelling on the potential that resides in poetry as a form of knowledge. In other words, modern poets, lacking cultural consensus upon which to ground their project, turn inward and speculate on the forms and structures of poetic discourse as a way of knowing the world. The "epic" poem, then, becomes not so much a search for universal or ultimate truths, but an emptying out of the forms knowledge has 
taken. This emptying out is "epic" because it is one of the major dilemmas that confronts poets at the present, the problem of creating forms of knowledge that resist becoming static and unchanging models of perception. In effect, then, what the contemporary epic depicts, at least in terms of Ashbery's poem, is the struggle with the condition of needing older forms and traditions in order to convey meaning, but remaining highly suspicious of them.

It is the continuing need for a shared sense of meaning and the skepticism towards any single concrete form meaning might take that preoccupies Ashbery. As much as this preoccupation is a shared cultural preoccupation, Ashbery's "Self-Portrait" meets Vogler's criteria for the inner form of an epic. There is, for instance, widespread acknowledgment of the "meta-fictional" or "self-reflexive" impulse within contemporary literature, which suggests some degree of common concern within various forms of aesthetic production. Thus, it should come as no surprise that a contemporary long poem meditates upon the possibilities and difficulties of the poetic imagination. What is remarkable about this widely shared self-reflexiveness, though, is that it constitutes a form of aesthetic faith--in the negative. To Vogler, epic offered a collective faith in poetry as a valid mode of perceiving reality, an embodiment of truth for a culture; for Ashbery, on the other hand, even that faith in poetry is something we can no longer have. Instead of establishing any privileged position or vision of human nature or "ultimate truths" in his poetry, Ashbery demonstrates their waning. It is this waning, this skepticism, which replaces Vogler's faith as the collective basis of the contemporary epic.

Tapping into the collective modernist negativity and skepticism towards inherited forms of consciousness and aesthetics, Ashbery's poem fuses the epic's summation of culturally shared dilemmas with the lyrical insight of the shorter poem. This, says Charles Altieri, is what is most distinctive about the modernist long poem, its "desire to achieve epic breadth by relying on structural principles inherent in lyric rather than narrative modes" ("Motives in Metaphor" 653). Only by relying on the "poetic logic" of the lyrical sort can 
the poem free itself from the distorting influences and ideology of traditional representation. The long poem, because it can overcome the limitations of ordinary logics by multiplying perspectives, voices and emotive contexts made available by the juxtaposition of lyric and epic, pushes the reader towards exploring implicit relational patterns as the only possible sources of thematic coherence (Altieri, "Motives in Metaphor" 653). However, even the modernist defense of the lyrical is a corruption produced by the cultural heritage (Altieri, "Motives in Metaphor" 654). The modernist defense of the imagination, with its promotion of the lyrical as a challenge to conventional notions of unity and coherence, is not a reaction that places it beyond the influence and ideology of "traditional representation," but is consonant with its vicissitudes. That is, the modernist reaction to the investment of cultural authority and explanatory powers in rationality is a response determined by the demystification of the imagination. The modernist defense of the lyrical sensibility is part of the cultural fabric and cannot be understood without it. Modernism's claims of revealing an alternative order amidst the chaos of the world are brought about by an earlier secularization and rationalization of the imagination. Modernism's claims of novelty and radical disruption from traditional forms and order are unfounded, especially since they cannot be understood except in relation to earlier movements and styles.

Modernism's defense and reification of the imagination is not only part of the heritage which Ashbery must confront, but is also part of the central conflict in American poetry today. It is a conflict between the romantic belief in the imaginative powers of the lyric sensibility and the enlightenment drive for demystification. Taking its form in ideals of lucidity and lyricism, says Altieri, enlightenment demystification and romantic valorization of the imagination leave us struggling with the conflicting impulses they have left us. Lyricism, as Altieri uses it, describes all attempts to use literature "for affirming in ostensibly secular forms predicates about the mind, person, and society that were the basic images of dignity and value in religious or 'organic' cultures" (Self and Sensibility 13); 
lucidity is a reaction to the pressures that drive writers to develop "psychic economies that can restore a world compatible with our imaginative forms of ideal personal qualities" (Self and Sensibility 13). Lyricism, as a result of enlightenment demystification, developed as an attempt to infuse reason, albeit in a secular form, with a divine or mythological basis. That is, enlightenment reason was double-edged: it allowed the demystification of belief at the same time it established a form of secular transcendence, a realm beyond speculation and dispute--whether that was reason itself or God. These contradictory needs gave rise to what Altieri calls "lucidity," the need to restore the power of imagination to secular mythologies. Enlightenment reason gives rise to our present conflicts because it bequeaths to us a need to demystify ideals, but also the need for idealizing of a set of values that resists all demystification (Altieri, Self and Sensibility 12):

Enlightenment thinkers wanted to preserve as many of the values sanctioned by religion as they could. This desire led them to create dual roles for their primary weapon--the ideal of reason. Reason could be wielded as an essentially critical instrument, seeking out and destroying structures of belief based on metaphor and superstitions only because reason also possessed positive values based in fact on the very Renaissance metaphoric system it was bent on destroying. (Altieri, Self and Sensibility 11)

Reason, then, was a critical tool that was used to demystify systems based on superstition and belief; but it was also a fictional creation, an artificially constructed set of values taken as the tool with which the natural order of the cosmos was revealed.

The secular form of an infusion of "organic" or imaginative values back into the aesthetic, the lyrical establishes the first-person experience as the source of authority and knowledge. But the lyrical also comes into conflict with enlightenment values, its skepticism of what cannot be empirically validated. The more the lyric values the personal, the romantic, the imaginative first-person account of experience, the more it conflicts with enlightenment emphasis on reason and objectivity. Modernism's need to defend the lyrical 
against traditional representation, far from showing that the conflict between values of "reason" and "romance" has passed, demonstrates how present the terms of this debate are. More importantly, contemporary American poetry can still be read for the signs of this conflict, as Altieri points out:

Once Enlightenment oppositions permeate our discourse about values, lyricism may be condemned to continual self-doubt. The models of what constitutes knowledge, or even what constitutes legitimate terms for discussing values, grow increasingly skeptical of what cannot be empirically demonstrated. Thus there is a constant temptation for poets to respond by rejecting impersonal thought and turning to the pure form of their myth, to the idea that it is only in terms of the intensity of firstperson experience that an authority for values can be established or defended. Yet once this move is made, there is no way even to talk about what the imagination discovers without bringing more doubts than clarity to what we would assert. (Self and Sensibility 13)

We saw earlier how contemporary critics and poets argue against the need and value of theory, which, in light of Altieri's remarks, leads us to understand their views as adhering to the need to defend the personal against the philosophical. Seeing critical theory and the philosophical poem as antithetical to the intensity of the first-person experience, segments of the poetic and critical communities reject "impersonal" (i.e., philosophical) thought as the only place where first-person authority and experience can be validated. However, as Altieri states, in turning more and more to the personal "intensity" of the first-person experience there is little ability for that "intensity" to be shared with others.

The tensions resulting from the conflict between "rational" and "romantic" values and their different attitudes toward public and private experience are apparent in the way poets attempt to grapple with reconciling first and third-person attitudes toward the lyric self (Altieri, Self and Sensibility 16). The lyric self, the lyric "I" provides "our deepest model of a fully personal inwardness" (Altieri, Self and Sensibility 16). But the tensions between the sincerity of attempts to describe the self and the public rhetoric needed to communicate such a phenomena leave contemporary poets in a difficult position. "The 
mystery, depth, immediacy, and essential privacy of our experiencing lyric emotions seems public testimony both to the uniqueness of private experience and to its ultimate communicability. If we can identify with what we read, we should be able to share similar experiences with those who participate in the same culture," says Altieri (Self and Sensibility 16). However, the very possibility of communication requires a dependency on a public discourse that seems a powerful invitation "to the ironic or deconstructive angel" (Altieri, Self and Sensibility 16). In other words, if "everything can be named in a public language, where does the "I" depart from the "he" or the "she," or where can we begin to present ourselves as unique by virtue of qualities of our subjective experience" (Altieri, Self and Sensibility 16$)$ ?

The much-noticed use of pronouns in Ashbery's work evokes the difficulties of first-person intensity and its interaction with a public form of discourse. Ashbery often uses them loosely, with an indefiniteness of reference. "It" is a major word in the Ashbery oeuvre and it is a sign of "the poet's epistemological hesitance" (Fite 69), his hesitancy in postulating lasting forms of meaning. "It" is often used in Ashbery's poetry as a sign without a clear or certain referent. "It" is often vague, ill-defined, or lost among any number of possibilities:

It is another life to the city, The backing of the looking glass of the Unidentified but precisely sketched studio. It wants

To siphon off the life of the studio, deflate Its mapped space to enactments, island it. That operation has been temporarily stalled

But something new is on the way, a new preciosity

In the wind. Can you stand it,

Francesco? Are you strong enough for it?

This wind brings what it knows not, is

Self-propelled, blind, has no notion

Of itself. It is inertia that once

Acknowledged saps all activity, secret or public ....

If it dissolves now

Into dust, that only means its time had come

Some time ago, but look now, and listen:

It may be that another life is stocked there 
In recesses no one knew of; that it,

Not we, are the change; that we are in fact it

If we could get back to it, relive some of the way

It looked, turn our faces to the globe as it sets ....

("Self-Portrait" 75-76)

At first the reader has a sense of referent for the "it" here, but it soon becomes obscured as the sentence passes through enjambment and further reference--as if the sense of "it" were not only large and undefined, but that "it" becomes an all-purpose category. "It" is sufficiently undefined so that it not only retains a sense of mystery, but the attribution also prevents any single form of meaning from emerging. "It," according to Fite, stands at a crucial place in Ashbery's poetry, where randomness and meaningfulness commingle (71). "It" is a location where Ashbery's poetics of in-betweenness emerge, where the naming of meaning and the resistance to naming takes place:

The details in which we see "it" manifest are all, in fact, metaphoric machinations for saying what is unsayable-unsayable not because transcendent, but because immanent and ongoing through multifoliate particulars. "It" is an unessentialized naming of the flux, of that "doing" which involves "the whole fabric," and the name must be indefinite, must be itself a turning away from essence, because the implicit recognition is that any attempt to say "it," to give expression to the ongoingness of things, is inadequate. (Fite 71)

"It" becomes a category without set or determined bounds. It names what cannot be named--Fites's "flux"--and as such suggests affinities both to the romantic ideal and the modernist order that were either always just out of reach or were to be discovered through art. However, in Ashbery, that ideal or order, the "it," is depicted as both always present on the surface of language and yet always receding before our very eyes. This is particularly clear throughout the poem as it alternates between the rhetoric of the self as pure surface and as never entirely present in and of itself. Regarding the mirror early on in the poem, the poet observes that "The time of day or the density of the light / Adhering to the face keeps it / Lively and intact in a recurring wave / Of arrival. The soul establishes itself" ("Self-Portrait" 68). The self in the portrait has a life, it is almost life-like in its 
ability to represent a self, to make it present to the viewer. There seems to be no difficulty in taking the representation at "face-value," that is, it is what it appears to be. However, the poet realizes that the portrait is a portrait, and not only a portrait but a portrait of a reflection in a mirror--a representation of a reflection:

But how far can it swim out through the eyes And still return safely to its nest? The surface Of the mirror being convex, the distance increases

Significantly; that is, enough to make the point That the soul is a captive, treated humanely, kept In suspension, unable to advance much farther Than your look intercepts the picture.

("Self-Portrait" 68)

The self, now, suddenly becomes more difficult to see, becomes more the effect of representation than the soul itself. The soul in the painting, the poet realizes, is "a captive," part of the art and not the object itself. This is an important opposition within the poem and it reflects the struggle of contemporary poets with the dependencies of the "I" on a public discourse while testing strategies for expressing the distinctiveness of that subjectivity.

Part of the dilemma this poem portrays, a dilemma which argues for its importance as a representative work of postmodernism, is how it grapples with the situation of attempting to forge new forms of expressing subjectivity--a situation that is complicated by the need to describe the subjective experience in a public language that does not reduce it to the conventions of public discourse. "Such balancing," says Altieri, "can involve complex redefinitions of how we understand the personal and impersonal, or the psychological and the rhetorical, as well as the possible interrelations among these poles" (Altieri, $\underline{\text { Self and }}$ Sensibility 16). This is the task that poets such as Ashbery accept as their own, an exploration of the continuing possibilities of the self that acknowledges its difficulties. That is, the desire for individuality and the desire to communicate public meaning run counter to each other. The desire to communicate, "the self projected as the vehicle for lyric experience" seeks a public identity, yet it can trust no public symbol or form as a

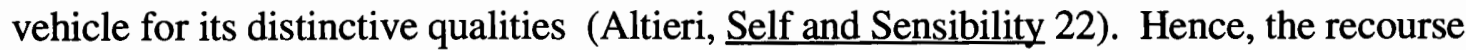


Ashbery has to the "it" which so often comes as a substitute for the "I" or the "we." Here, for instance, the fluidity between "it" and "we" is typical:

It may be that another life is stocked there

In recesses no one knew of; that it,

Not we, are the change; that we are in fact it

If we could get back to it ....

("Self-Portrait" 76)

What this viscous pronoun usage suggests, then, is that it arises from a romantic and/or modernist impulse that believes itself able to reveal an alternative order, but which, so it implies, is also beyond expression or the limits of our understanding. "It" is Ashbery's syntactical equivalent of the "divine" or the Whitmanian "self" in which all things are reflected. Ashbery's pronouns, too, respond to the contemporary dilemma of being skeptical of the conventions of expression that place such "transcendent" ideals into static models. "Self-Portrait" reflects the desire to express a lyrical self, an "it," that is individual but does not have to depend on the past for models of subjective expression. The poet suggests that our dependence on others, on a public and shared discourse, is where the construction of self takes place:

I think of the friends

Who came to seem me, of what yesterday

Was like. A peculiar slant

Of memory that intrudes on the dreaming model

In the silence of the studio as he considers

Lifting the pencil to the self-portrait.

How many people came and stayed a certain time,

Uttered light or dark speech that became part of you

Like light behind windblown fog and sand,

Filtered and influenced by it, until no part

Remains that is surely you. Those voices in the dusk

Have told you all and still the tale goes on

In the form of memories deposited in irregular

Clumps of crystals.

("Self-Portrait" 71)

Note that it is not so much the poet or the artist--it could be either here--that constructs the self-portrait, but the others who talk about it. The "peculiar slant / Of memory" is important here in this respect; invoking Dickinson, the passage implies that her presence 
has an influence on what it is that comes to be created as self. What she has had to say exerts its influence on what and how Ashbery the poet is able to create a version of subjectivity in the poem. The passages amplifies this idea as it states how the public discourse alters one's own version of subjective experience, "like light behind windblown fog and sand / Filtered and influenced by it," and leaves nothing that might be considered "I." Dependent on what has been said, the poet recognizes the fact that it is not so much what one wishes to express that gets spoken, but, instead, what is able to be expressed within a common public language. What has been said about self, the inherited ideas of self, these frame even the very possibility of saying " $\mathrm{I}$ " and determine its limits. It is not what an "I" has to say about self that gets expressed, but the understandings that are currently circulating about self.

Recognizing the need of poetry to be both personal and sincere and also to acknowledge the public discourses and conventions through which the self is formed or described, Ashbery opens his poetry "to a play of tensions between the self represented and the variety of motives that go into the process of producing and using representations" (Altieri, Self and Sensibility 17). By opposing the notion of a "sincere" self, the one romantic poets posit as always beyond language, to the "artificial," rhetorical construction of self, Ashbery's "Self-Portrait" acts out a drama of the construction of self as poem. Ashbery plays on the opposition between the supposed "sincere" self beyond language and the rhetorical constructions of self in poetry. He plays on the opposition between sincerity and deception, sincerity as that which escapes expression in language and deception as that which shows the poet as an artificer. To foreground the rhetorical nature of self, to show "self" as always a construction, exposes the poet's secret: a desire for public significance while maintaining a deep, uninterpretable source of energy ensuring that the self does not simply become an actor on a public stage (Altieri, Self and Sensibility 24). Ashbery explores the interdependent nature of duplicity and sincerity in order to show that the 
"representing self must share stage time with the dramatized actor playing his or her roles within a single constructed scene" (Self and Sensibility 17$)$. 


\section{Chapter Five}

\section{Refracting Postmodernism}

In "Self-Portrait," then, we see an oblique stance towards literary tradition and history, an ambivalence towards romantic and modernist impulses, and an interrogation of the conventions of authorship and originality. Because of Ashbery's deflation of tradition, his purging of the idealized forms of authorship and originality, and his undermining of humanistic notions of poetry and subjectivity, it is little wonder he is so associated with postmodern aesthetic practices. However clear these practices might appear, though, the poem's ambivalence and undecidedness towards them makes it more difficult to situate the poem conveniently within the postmodernist genre. While Ashbery's pastiche of the cultural and aesthetic past suggests an affinity with American versions of postmodernism, that easy attribution also overlooks the poet's own uneasy relationship with such a categorization. Quite often Ashbery's poetry is determined by a relationship with the aesthetic past that divests the work of "high" art of its aura, while also reinforcing the divide between high and popular culture that postmodernism supposedly works to undermine. In order to get the joke of Ashbery's poetry, in other words, it is necessary to know what it is so often parodies: aesthetic modernism. "Self-Portrait," working to undermine the aesthetic idealism of modernism, predicates itself on two contradictory strains of modernism: the high modernist tradition which, providing idealized images to be purged of transcendental value, also maintains the distinction between itself and the popular; and the late-modernist or postmodern refraction of that distinction which mingles 
the high and the popular. Postmodernism, then, contains no simple relation to the aesthetic past, but is made up of conflicting impulses: while distancing itself from the past through demystification and juxtaposition, it must retain that past as making the present possible. This ambivalent tension serves more to reinforce the distinction between the high and the popular than to undermine it. It also prevents any untroubled identification of Ashbery as postmodern.

Andreas Huyssen's book, After the Great Divide, characterizes the postmodernism of the 1970s as having been constituted by the same conflicting strains of modernism that appear in Ashbery's work. There is, in this version of postmodernism, "an ever wider dispersal and dissemination of artistic practices all working out of the ruins of the modernist edifice, raiding it for ideas, plundering its vocabulary and supplementing it with randomly chosen images and motifs from pre-modern and non-modern cultures as well as from contemporary mass culture" (196). Modernist styles, Huyssen adds, were abolished, but continued as part of mass culture. This appropriation of modernist images from a "cultural storage bank," making the whole history of various artistic techniques, forms, and images stored and available for instant recall, marks the crossing of Huyssen's "great divide": that between high modernism and mass culture. It is a divide that no longer seems relevant to postmodern aesthetic sensibilities, says Huyssen (197). The problem, then, of situating Ashbery as a late modern or a postmodern is complicated by an aesthetic culture and ideology that has largely abandoned the distinction between "mass" and "high" culture. However, while Ashbery often obscures these sorts of distinctions, he also retains the highly sophisticated philosophical subjects of modernism. It is his continuing philosophical engagement with modernist issues that seems so problematic in assigning him a postmodern status. Ashbery's engagement with modernism suggests not so much an affiliation with postmodernism as much as it does with the aesthetic forms and intellectual concerns of modernism. 
Part of the "New York School," Ashbery was not only a part of the scene that included such American modernist movements as Abstract Expressionism, but, more poignantly, was even part of the established "institutions" of high art. An editor for Art News and a reviewer for the Herald Tribune in France, Ashbery is clearly associated with what Andreas Huyssen observes to be that cultural moment in the 1950s and early 1960 s when modernism entered the mainstream. This moment marks, says Huyssen, the emergence for the first time of something that can be considered "institution art." The irony in this institutional status for modernism was that it had sought to resist the sort of bourgeois cooption into marketability and commodification that it suddenly found itself subject to during the 1950s and early 1960s (Huyssen 193). Part of this moment that saw the "institutionalization" of modernism, Auden's early identification of Ashbery as being the heir of Rimbaud (Bloom 49-50) is significant because it shows the emerging development of a perception of him as aligned with the "high" art tradition of modernism and not with the more "populist," resistant strains of avant-garde in the late 1950s and early 1960s.

The "pop" culture that developed later in the 1960s, Huyssen notes, was part of an attempt to recapture the "adversary ethos" that was so much a part of modernism in its earlier stages, but which had been lost in its "institutionalization." Ashbery's relationship with this "adversarial" culture and art was primarily shaped by his place within the traditional "institutions" of high art. His interests and aesthetics clearly reflect an on-going preoccupation with modernism as much as a fascination with the popular. It is from within his position within the institutional forms of modernism that Ashbery's relationship toward the more resistant varieties of culture was formed. As Ashbery says of a painter he reviewed in Art News, but applicable to himself as well, "his own work is constantly undergoing changes which take new esthetic developments into account, without necessarily conforming to them" (Ashbery, "Absence and Illusion" 33). Although he 
embraced aspects of "pop" art that were popularized in the late 1960s, there is very little sense in which we can see him as a "popular" poet. His poetry is, quite often, dense and opaque, difficult and obscure, largely because of the intellectual paradigms and aesthetics he makes use of. However, associated with this "high" philosophical subject matter Ashbery uses to construct his poems is the "low" to which these highs are brought, as if to show the limits of such aesthetic ambitions. This, it seems, is the more "populist" gesture in Ashbery, using popular culture as a means of demystifying and ironizing the epistemological claims of modernist aesthetic idealism. For example, in comments on Picasso made in Art News in 1971, Ashbery mingles a traditional homage to high modernist aesthetics with the pop culture of commercial jingle:

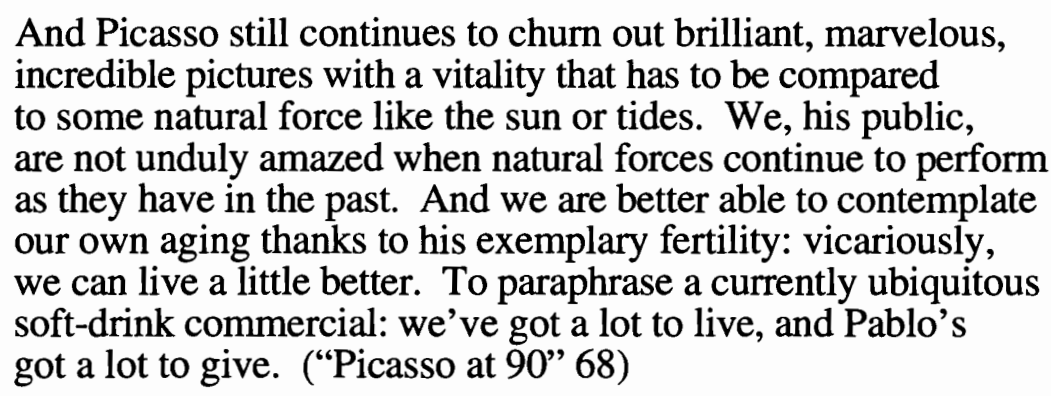

The "natural force" of Picasso's "fertility" is brought low by its association with an advertisement for a soft-drink. The mystery of Picasso's "vitality" is summed up in a jingle. Ashbery sets up and then prevents the idealistic language from proceeding too far, retaining the idealism but commodifying it, bringing it to the level of a popular slogan. It is as if the inspiration of modernism, its "natural force," is denied any ability to leave the plane of the popular. We see this impulse, as well, in a later article where Ashbery draws a parallel between the techniques of abstract-expressionism and a comic strip:

There was once a Mutt and Jeff strip in which Jeff had gone into business selling honey with a dead bee in each jar as a proof of genuineness and frantic brushwork is often the dead bee in Abstract-Expressionist painting.

("Absence and Illusion" 33) 
Looking at modernism through popular culture, Ashbery's equating the brushwork of Abstract Expressionism to Mutt and Jeff's dead bee undermines the use-value of the "genuine." It questions the need for it, wonders if it actually does any good at all.

Two aspects, then, of Ashbery's relationship to modernism are important. First, he is much more clearly associated with a "mainstream" culture of modernism and its institutional forms than with a resistant or adversarial form of the avant-garde or popular culture; and, second, while not a "populist" poet, Ashbery intermingles "high" and "low" cultures through a juxtaposition of what we might call "low" aesthetic form and "high" philosophical subject. Both of these aspects allow us to see more clearly how "SelfPortrait" and Ashbery fit the cultural moment of a 1970s postmodernism that now looks to us much more like a version of modernism.

What is most difficult about an unequivocal attribution of Ashbery's postmodernism is that his residual idealism is more in agreement with modernism than it is with the aesthetic leveling of postmodernism. Huyssen is helpful on this point. He notes that the association of postmodernism and poststructuralism, almost a commonplace in academic discussions, is not as clear cut as might appear. Instead, he says, poststructuralism, to a significant degree, is a theory of modernism (207).

If it is true that postmodernity is a historical condition making it sufficiently unique and different from modernity, then it is striking to see how deeply the poststructuralist critical discourse--in its obsession with écriture and writing, allegory and rhetoric, and in its displacement of revolution and politics to the aesthetic--is embedded in that very modernist tradition which, at least in American eyes, it presumably transcends. (Huyssen 207-208)

According to Huyssen, it is the aesthetic idealism, the faith in textuality, the privileging of writing, that reveals poststructuralism's closer affinity to modernism, not postmodernism. Modernism's aesthetic innovation and experiment, its self-reflexiveness, its purging of reality and history from art, its insight that the subject is constituted in language--these all 
create a new version of the autonomy of art. An art for art's sake view, the poststructural version of modernism abandons faith in art's potential to change the world. It is in valuing these refracted and selective characteristics of modernism that poststructuralism elaborates not a theory of postmodernism, but modernism.

The selective reading poststructuralism does of modernism creates a modernism "of playful transgression, of an unlimited weaving of textuality, a modernism all confident in its rejection of representation and reality, in its denial of the subject, of history, and of the subject of history" (Huyssen 209). It is a very different modernism than the modernism of negativity and alienation. It is as if the critique of bourgeois modernism and modernization has not only been jettisoned from the modernist project, but its self-incurred responsibilities "to change life, change society, change the world" (Huyssen 210) are now seen as deluded attempts that stepped beyond the realm of art. It is as if in the poststructural version of modernism those visions of influencing the world through art have been abandoned in favor of a retreat into an aestheticism of writing. But as Huyssen says of poststructuralism's promotion of écriture, it not only reaffirms the divide between popular and high culture, it is also a sign of the inconsistencies of contemporary critical thought. In its attempts to pass off a regenerated version of modernism as the latest avant-garde in criticism or poetry, poststructuralism tries to salvage what it has sought to distance itself from:

To insist on the adversary function of écriture and of breaking of linguistic codes when every second ad bristles with domesticated avantgardist and modernist strategies strikes me as caught precisely in that very overestimation of art's transformative function for society which is the signature of an earlier, modernist, age. (Huyssen 210)

Finding it rather absurd that poststructuralism tries to pass off a selective version of modernism as the latest avant-garde in aesthetics and criticism, Huyssen questions "the 
notion of a radical rupture between the modern and the postmodern ..." (208). This lack of rupture where one is often predicated is most apparent in the sort of work attempted by poststructuralist criticism, says Huyssen, particularly in its emphasis on modernist, not postmodernist, works of literature or art:

It is furthermore striking that despite the considerable differences between the various poststructuralist projects, none of them seems informed in any substantial way by postmodernist works of art. Rarely, if ever, do they even address postmodernist works. In itself, this does not vitiate the power of the theory. But it does make for a kind of dubbing where the poststructuralist language is not in sync with the lips and movements of the postmodern body. There is no doubt that center stage in critical theory is held by the classical modernists: Flaubert, Proust and Bataille in Barthes; Nietzsche and Heidegger, Mallarmé and Artaud in Derrida; Nietzsche, Magritte and Bataille in Foucault; Mallarmé and Lautréamont, Joyce and Artaud in Kristeva; Freud in Lacan; Brecht in Althusser and Machrey, and so on ad infinitum. The enemies still are realism and representation, mass culture and standardization, grammar, communication, and the presumably all-powerful homogenizing pressures of the modern State. (Huyssen 208-209)

Ashbery's own poetic project is very similar to the sorts of readings the poststructuralists undertake of modernism. His accommodation to poststructuralist readings during the 1970 s and 1980 s attests to the easy interface between the theory of poststructuralism--as a theory of modernism--and the practice of his poetics. Ashbery fits into a view of postmodernism as modernism in his critique of realism and representation, originality and authorship, while maintaining a residual aesthetic idealism, an attempt to salvage aesthetic modernism--the privilege and idealism reserved for an aesthetics of writing. Ashbery retains a faith in the poetic imagination and, most importantly, in writing itself as an artistic medium able to fashion unique and profound insights--no matter how fleeting and transitory these might be. Ashbery has certainly abandoned the sorts of modernist "visions" of aesthetic idealism that sought to change the world, but this reduction of the "transformative power of art" to a game, an endless source of possibilities, marks Ashbery as being much closer to what Huyssen identifies as a typically 1970 s model of 
(post)modernism--a version of modernism preoccupied with the aesthetics of writing as a retreat from those earlier "visionary" modernisms. It is in this particular affirmation of aesthetic idealism that the divide between popular culture and the high culture of modernism reinsinuates itself within a refracted version of modernism and contributes to the placement of Ashbery in the context of a 1970s (post)modernism more closely resembling a late version of modernism.

John Ashbery's "Self-Portrait in a Convex Mirror," then, is an important textual indicator of the sorts of changes that have taken place within contemporary theory and poetry in the last thirty years. The poem is an artifact of the impulses and ideas that have revised our ways of talking about such things as literature. Ostensibly postmodern, Ashbery's poem problematizes the sorts of arbitrary distinctions and idealistic motives that have traditionally informed aesthetic production, undermining them, subverting them, restlessly building and destroying them. Erasing the sharp distinction between poetic and theoretical discourses, the poem shares the postmodern milieu in which such distinctions are shown to be the result of political exclusions and conscious choices--not necessarily the value-free, "objective" decisions they have so often been made out to be. Foregrounding the aesthetic choices and exclusions that are always being made in art, the poem resembles a poeticized theoretical discourse. It is self-consciously theoretical, particularly as it seems to share the cultural preoccupation with what it means to represent human consciousness. That is, taking as its subject the nature of representing the human consciousness, the poem engages with postmodern theory, shares its view of the human subject as the creation of both language and ideology.

What is particularly striking is the manner in which the poem's revision of the subject is paralleled by the same sorts of revisions within academia. At roughly the same 
time as Ashbery is undertaking his own revision of the subject, postmodern theory is beginning to have an impact upon the structure and discourse of the university. Questioning the divisions and distinctions of knowledge that constitute the institution of the university, postmodern theory has opened up new varieties of discursive practices, practices that have made possible interactions among disciplines that have not historically been associated.

Within the division of literature itself, there has been a massive undertaking to show how "constructed" its subject is. Studies like Graff's Professing Literature share the postmodern preoccupation for revisiting the past in order to show how what has so often been represented as stable, coherent, and transhistorical has actually been carefully constructed to suit political and social contingencies. As a representation of the human subject, literature itself, which historically has been requisitioned to show the transhistorical essence of "man's" nature, is finding itself under increasingly skeptical interrogations about what ethical values can or should be conjoined with particular aesthetic readings. While equally politicized, postmodern revisions of the stability and coherence of the subject of literature attempt, at least, to foreground their readings as always political, as always ideologically motivated.

The traditional distinction between theory and poetry is itself highly politicized. Within literature, the divisions between theorists and poets remain a constant reminder that there are always competing versions of what literature is or should be about. But what is most useful in postmodern theory and poetry is how it attempts to revise our understanding of just this kind of binary opposition. By showing how "constructed" and arbitrary the distinction is between theory and poetry, by taking apart the differences between them, postmodernism indicates that it is more useful to examine their relationships and interactions. Ashbery's "Self-Portrait" is valuable, then, not simply as an artifact of this climate, an indication of its impulses and practices, but as an enactment of the erasure of 
arbitrary distinctions, distinctions less useful when placed in mutual opposition and much more useful when able to interact freely. As Ashbery demonstrates, the results of such interactions indicate both our need for them, our continued dependence on them, and the restrictions they contain us within. It is Ashbery's mingling of conflicting strains of inherited discursive, ideological, and aesthetic practices that is, finally, most remarkable. "Self-Portrait," acting as a stage, allows competing impulses and vocabularies to neutralize and cancel each other out, pointing to both the inadequacy of past formulations and the uncertainty of the not yet--leaving us only the present. 


\section{Works Cited}

Abrams, M.H. A Glossary of Literary Terms. 5th Edition. Fort Worth: Holt, Rinehart and Winson, Inc.: 1988.

Altieri, Charles. Self and Sensibility in Contemporary American Poetry. Cambridge: Cambridge University Press, 1984.

-----. "Contemporary Poetry as Philosophy: Subjective Agency in John Ashbery and C.K. Williams.” Contemporary Literature. Summer (1992): 214-242.

----. "Motives in Metaphor: John Ashbery and the Modernist Long Poem." Genre. Winter (1978): 653-687.

Ashbery, John. "Picasso at 90." Art News October (1971): 68-69.

-----. “Absence and Illusion.” Art News May (1972): 32-62.

----. "Self-Portrait in a Convex Mirror." Self-Portrait in a Convex Mirror. New York: Penguin, 1976

Bloom, Harold. John Ashbery. New York: Chelsea, 1985.

Bruss, Elizabeth. Beautiful Theories: the spectacle of discourse in contemporary criticism. Baltimore: Johns Hopkins University Press, 1982.

Culler, Jonathan. "Beyond Interpretation: The Prospects of Contemporary Criticism." Comparative Literature. Summer (1976): 244-256.

----. "Poststructuralist Criticism." Style 21 (1987): 167-180.

Fite, David. “On the Virtues of Modesty: John Ashbery's Tactics Against Transcendence." Modern Language Quarterly. 42 (1981): 65-84.

Foucault, Michel. The Order of Things: An Archaelogy of the Human Sciences. New York: Vintage Books Edition, 1973.

Graff, Gerald. Professing Literature: An Institutional History. Chicago: The University of Chicago Press, 1987.

Hartman, Geoffrey. "Crossing Over: Literary Commentary as Literature." Comparative Literature. Summer (1976): 257-276.

Holden, Jonathan. The Fate of American Poetry. Athens: The University of Georgia Press, 1991. 
Huyssen, Andreas. After the Great Divide: Modernism, Mass Culture, Postmodernism. Bloomington: Indiana University Press, 1986.

Johnston, John. “Postmodern Theory/Postmodern Fiction.” CLIO 16 (1987): 139-158.

Lazer, Hank. "Critical Theory and Contemporary American Poetry." What is a Poet? Essays from the Eleventh Alabama Symposium on English and American Literature. Ed. Hank Lazer. Tuscaloosa: The University of Alabama Press, 1984.

Paulson, William. The Noise of Culture. Ithaca, New York: Cornell University Press, 1988.

Rorty, Richard. Contingency, irony, and solidarity. Cambridge: Harvard University Press, 1992.

Sokolsky, Anita. "A Commission That Never Materialized": Narcissism and Lucidity in Ashbery's "Self-Portrait in a Convex Mirror" in Modern Critical Views John Ashbery Ed. Harold Bloom. New York: Chelsea House Publishers, 1985.

Valéry, Paul. "Poetry and Abstract Thought." The Art of Poetry. Volume 7 of The Collected Works of Paul Valéry. Trans. Denise Folliot. New York: Pantheon Books, 1958.

Vogler, Thomas. Preludes to Vision: The Epic Venture in Blake, Wordsworth, Keats, and Hart Crane. Los Angeles: University of California Press, 1971.

Whitman, Walt. Leaves of Grass. Ed. Malcolm Cowley. United States of America: Penguin Classics, 1986.

Zavarzadeh, Mas'ud; Morton, Donald. "Theory Pedagogy Politics: The Crisis of "The Subject' in the Humanities." Ed. Zavarzadeh and Morton. Theory/ Pedagogy/ Politics: Texts for Change. Urbana: University of Illinois Press, 1991 